\title{
A review of recent studies on the life history and ecology of European cephalopods with emphasis on species with the greatest commercial fishery and culture potential
}

\author{
F. Lishchenko ${ }^{\mathrm{a}, *}$, C. Perales-Raya ${ }^{\mathrm{b}}$, C. Barrett $^{\mathrm{c}}$, D. Oesterwind ${ }^{\mathrm{d}}$, A.M. Power ${ }^{\mathrm{e}}$, A. Larivain ${ }^{\mathrm{f}}$, \\ V. Laptikhovsky ${ }^{\text {c }}$, A. Karatza ${ }^{g}$, N. Badouvas ${ }^{g}$, A. Lishchenko ${ }^{\mathrm{a}}$, G.J. Pierce ${ }^{\text {h,i }}$ \\ ${ }^{a}$ A.N. Severtsov Institute of Ecology and Evolution, Laboratory for Ecology and Morphology of Marine Invertebrates, 119071, 33 Leninskij Prosp., Moscow, Russia \\ ${ }^{\mathrm{b}}$ Instituto Español de Oceanografía, Centro Oceanográfico de Canarias. Calle Farola del Mar, 22, 98180, Santa Cruz de Tenerife, Spain \\ ${ }^{\mathrm{c}}$ Centre for Environment, Fisheries and Aquaculture Science, Pakefield Road, Lowestoft, Suffolk, NR33 OHT, United Kingdom \\ ${ }^{\mathrm{d}}$ Thünen Institute of Baltic Sea Fisheries, Alter Hafen Süd 2, 18069 Rostock, Germany \\ ${ }^{\mathrm{e}}$ Ryan Institute, School of Natural Sciences, National University of Ireland Galway, University Road, Galway, Ireland \\ ${ }^{\mathrm{f}}$ Université de Caen Normandie, FRE 2030 BOREA Biologie des ORganismes et Ecosystèmes Aquatiques, équipe EcoFunc, MNHN, SU, UCN, CNRS, IRD, UA, Caen, \\ France \\ ${ }^{\mathrm{g}}$ Hellenic Centre for Marine Research, 19013 Anavyssos, 46,7 Km Athens Sounio Ave., Greece \\ ${ }^{\mathrm{h}}$ Instituto de Investigaciones Marinas (CSIC), Eduardo Cabello 6, 36208 Vigo, Spain \\ ${ }^{\text {i }}$ School of Biological Sciences, University of Aberdeen, Zoology Building, Tillydrone Avenue, AB24 2TZ, Aberdeen, UK
}

\section{A R T I C L E I N F O}

\section{Keywords:}

Cephalopods

European waters

Life history

Fisheries

Aquaculture

\begin{abstract}
A B S T R A C T
With the depletion of many commercial fish stocks and an increasing demand for marine protein for human consumption, cephalopods have become more important as a fishery resource. In EU waters, cephalopod stocks are not routinely assessed and exploitation of these species by large-scale fisheries is largely unregulated. For sustainable exploitation, adequate assessment and scientifically-supported management strategies are needed. However, there is still a lack of data on stock status and inadequate knowledge of the life history and ecology of these species. The present review examined more than 200 scientific articles, on life history and ecology of European cephalopods, published since 2013. It describes recent contributions to knowledge in the context of previously identified research priorities, along with recent advances towards sustainable fishing and aquaculture. It also identifies outstanding knowledge gaps. While some priority areas, such as the development of the species identification guides and evaluation of climate change impacts on cephalopods, have seen significant advances, other challenges remain for the future. These include monitoring of the life history traits and fishery status for the main commercially exploited species in the area, implementation of improved species identification methods during scientific surveys and fisheries monitoring, development of tools to identify stock units, and the study of the environmental and anthropogenic impacts on the stocks of cephalopods inhabiting European waters.
\end{abstract}

\section{Introduction}

Wider recognition of cephalopods as key elements of marine ecosystems (Gasalla et al., 2010; de la Chesnais et al., 2019), evidence of increasing cephalopod abundance (Doubleday et al., 2016), and their potential to replace traditional fishery resources (Caddy and Rodhouse, 1998; Hunsicker et al., 2010; Rodhouse et al., 2014) have led to increased interest in these animals from the scientific community (e.g. Arkhipkin et al., 2015; Jereb et al., 2015). However, in European waters, cephalopods continue to be considered as minor fishery resources, not covered by the EU Common Fisheries Policy. While cephalopods are targeted by many small-scale fisheries, in most large-scale fisheries they are landed as a bycatch. Consequently, fished stocks are not well defined, monitoring of their status is limited and there is no routine assessment of stock status. There are no quota limits for cephalopod catches, although some EU countries specify minimum landing sizes and many directed small-scale fisheries are heavily regulated (see Pierce et al., 2010; Jereb et al., 2015).

\footnotetext{
* Corresponding author.

E-mail address: filiusferro@gmail.com (F. Lishchenko).
} 
A comprehensive review by Jereb et al. (2015) identified various knowledge and implementation gaps hindering the achievement of sustainable fisheries and culture of the main cephalopod resource species in European seas. These gaps (not all applying to all species) included (i) environmental effects on life history, distribution and abundance, including effects of climate change; (ii) age estimation techniques; (iii) basic life history traits; (iv) inferences on life history and ecology from studies of trace element and isotope composition of hard structures; (v) stock assessment; (vi) diet and nutrition.

Here, we review recent publications on life history, ecology, and fisheries of a key cephalopod species exploited in European seas to assess progress in filling these gaps. The following species were chosen for review based on the level of (or potential for) commercial exploitation and their distribution: octopuses - Octopus vulgaris, Eledone cirrhosa, Eledone moschata; cuttlefishes - Sepia officinalis, S. elegans and S. orbignyana; sepiolids - Sepietta oweniana and squids - Loligo vulgaris, Loligo forbesii, Alloteuthis subulata, Alloteuthis media, Illex coindetii, Todarodes sagittatus, Todaropsis eblanae, Ommastrephes caroli ${ }^{1}$ and Gonatus fabricii.

\section{Materials and methods}

Over 200 journal articles devoted to studies of life history, distribution, trophic relationships, taxonomy, fisheries and impact of climate change on these species have been published during the last seven years (from 2013) and these articles form the main source material for the present review. The articles published before the second half of 2013 were not reviewed because they were comprehensively considered in ICES cooperative research report (Jereb et al., 2015). We have not specifically included edited books but note that at least four relevant volumes were published between 2013 and 2019, concerning squid biology (Rosa et al., 2013a, b), cephalopod aquaculture (Iglesias et al., 2014) and pathology (Gestal et al., 2019). Several published papers have examined global trends in cephalopod abundance, for example related to climate change and other anthropogenic impacts on the oceans (Doubleday et al., 2016; Doubleday and Connell, 2018), focused on fisheries and fishery management issues (Arkhipkin et al., 2015; Sauer et al., 2019) or looked broadly into the future of cephalopod research, notably Xavier et al. (2015) and O'Brien et al. (2018), but our focus here is more specific.

To simplify the tracking of updates on the fields of interest identified in the previous review (Jereb et al., 2015) the present review was structured in a similar way. In particular, the whole review was split into species-specific sections, which, in turn were split into subsections on different fields of research. For each species, the sub-section headings are drawn from the following list, although some or all sub-sections headings were omitted when there was insufficient information available to report:

1 Introduction - the main knowledge gaps, identified by Jereb et al. (2015) are described along with an overview of the recent developments in these fields and priorities / promising fields for the future research;

2 Environmental effects, distribution and abundance: summarizing new findings on environmental impacts on cephalopods, including the impacts of climate change and pollution, along with new information on distribution and abundance of the species in European waters;

3 Life history, including basic life history traits and information on age, growth, reproduction, etc.;

\footnotetext{
${ }^{1}$ It has recently been proposed to split Ommastrephes bartramii into three species, with the European specimens now belonging to O. caroli (Fernández-Álvarez et al., 2020) and we therefore now use the latter designation although the existing literature refers to $O$. bartramii.
}

4 Ecology, mainly focused on trophic ecology and other interspecific interactions;

5 Fishery management and conservation, including fishing methods, stock assessment, regulations, etc.;

6 Culture and welfare, including the development of aquaculture methods, diet and nutrition, and welfare practices;

7 Other studies: other new information relevant to the sustainable exploitation of the species, which did not readily fit into any of the sections above, for example information on identification guides, physiology, behaviour and use of cephalopods in new fields of science.

In addition to the species-specific sections, two further sections, 'Summary' and 'Concluding remarks' present a broader discussion on the development of the fields of interest, identified in the previous review (Jereb et al., 2015) and addressing the present knowledge gaps, respectively.

Most of the recently published studies consulted were devoted to four of the 16 cephalopod species mentioned above, namely O. vulgaris, ${ }^{2}$ $S$. officinalis, L. vulgaris and I. coindetii. The high number of papers on common octopus $O$. vulgaris and common cuttlefish $S$. officinalis (51 and 54, respectively) reflects their importance for European fisheries and the interest in developing commercial aquaculture. Both species are intensively exploited by fisheries across their range, providing the highest catches among cephalopods in European waters. Thanks to relatively well-developed methods for rearing in captivity, common octopus and common cuttlefish also serve as models in a wide variety of studies (Jereb et al., 2015). Loligo vulgaris and $I$. coindetii, are the main commercially exploited species of (respectively) myopsid and oegopsid squids in Europe. Depending on the region and season, L. vulgaris can contribute up to $90 \%$ of total loliginid catches while $I$. coindetii makes up as much as $80 \%$ of ommastrephid landings (Jereb et al., 2015). The genus Ommastrephes has been studied mainly in the Pacific. At the time we started work on this review, Atlantic and Pacific populations were both considered to belong to $O$. bartramii and more than $90 \%$ of the articles reviewed were devoted to studies of Pacific populations. The remainder refer to what has now been designated as $O$. caroli in the Atlantic and Mediterranean.

\section{Octopus vulgaris}

\subsection{Introduction}

The common octopus Octopus vulgaris, once considered to be a single cosmopolitan species, is now recognized to be a cryptic species complex (Amor et al., 2017), with multiple O. vulgaris-like species. The one identified as Octopus vulgaris sensu stricto occurs in the Mediterranean and North East Atlantic (Amor et al., 2017), with a complex population structure and two main divergent haplogroups as suggested by Quinteiro et al. (2020): one has a distribution focused in northern waters and other is primarily southern, with both occurring in the Mediterranean Sea. The geographical range occupied by the southern group extends from temperate-tropical Macaronesian waters $\left(32^{\circ} \mathrm{N}\right)$ to South Africa $\left(35^{\circ} \mathrm{S}\right)$.

Jereb et al. (2015) identified the following topics as important for future research in the species: (1) the influence of environmental conditions on wild populations, (2) early life stages and (3) development of inert diets or microencapsulated products to produce enriched Artemia for feeding paralarvae.

More than 100 journal articles were published about Octopus vulgaris during the period from 2013 to 2020 . Recent studies on environmental effects allowed identification of external factors affecting the

\footnotetext{
${ }^{2}$ As will be discussed in the following section, Octopus vulgaris is currently regarded as a species complex rather than a single species, although European animals are considered to belong to the species $O$. vulgaris sensu stricto.
} 
distribution, migration and survival of adult octopuses and provided information on the impact of environmental/rearing conditions on the paralarvae. This knowledge should facilitate faster growth and better survival, along with improvement of quality of life for reared larvae. Various approaches to feeding octopus paralarvae in culture and analysis of the effect of dietary nutritional composition on the composition and development of octopus tissues contributed to better understanding of hatchlings and juvenile nutritional requirements. In addition, a considerable number of recent studies concerned age estimation, growth rates, parasite infections, morphology and the reproductive biology of O. vulgaris. Nevertheless, topics 2 (early life stages) and 3 (feeding paralarvae) continue to be areas in which further work is needed.

\subsection{Environmental effects, distribution and abundance}

Previous studies on Octopus vulgaris have highlighted the need to understand the influence of environmental conditions on wild populations (see Jereb et al., 2015). Recent studies have examined the influence of temperature, salinity and the availability of shelter on individuals and populations. Moreno et al. (2014a) showed that changes in bottom salinity and river runoff are major influences on O. vulgaris distribution and abundance. Salinity changes also affect the intensity of feeding and survival of octopuses (Amado et al., 2015; Iglesias et al., 2016), with low salinity leading to reduced food consumption and the cessation of feeding. Decreased salinity during runoff events can be fatal to octopus due to disruption of osmoregulation (Raimundo et al., 2017). However, octopuses can survive reduced water salinity (not lower than $30 \mathrm{psu}$ ), at least for short periods. Castellano et al. (2018) tested tolerance to seawater dilution in paralarvae of $O$. vulgaris Type II (i.e. octopus from the Western South Atlantic, Amor et al., 2017). They concluded that paralarvae tolerate some deviation from normal seawater salinity, displaying osmoconforming behaviour, maintaining body hydration and a high tissue volume/water regulation ability over short periods of time. This capacity might be one factor allowing their dispersal and survival in environments with moderate deviations from normal seawater salinity.

Schwarz et al. (2018) investigated effects of environmental forcing on lifespan in 25 species of octopus, including both $O$. vulgaris and E. cirrhosa, finding a negative power function relationship $\left(\mathrm{r}^{2}=0.86\right)$ between age at maturity and average habitat temperature.

Environmental impacts on octopus abundance and the reproductive season in the Western Mediterranean are described by García-Martínez et al. (2018), who suggest that environmental temperature can determine the timing of the onset and the duration of the spawning period, the number of spawning peaks and the duration of both the embryonic and paralarval phases. Alonso-Fernández et al. (2017) showed that the post-settlement population sex ratio of $O$. vulgaris in the North East Atlantic varied along the bathymetric gradient and between seasons. Male dominance was observed in summer, while autumn populations were female-biased. A larger proportion of females was observed in deeper waters during winter and spring. On the other hand, catches of females were lower in summer on hard substrates. The authors assumed that catches were highly influenced by sexual behaviour and life history of octopuses (i.e. in summer females breed egg masses in dens, where they are unavailable to fishing gear).

Human impacts on coastal habitats can have both negative and positive effects on octopus. Sillero-Ríos et al. (2018) studied oxidative stress mechanisms in $O$. vulgaris in coastal areas with different degrees of human activities or impacts in the Mediterranean Sea. Antioxidant enzyme activity in octopus from a marine reserve was significantly lower than in octopus from two anthropogenically-impacted areas. However, Arechavala-Lopez et al. (2019) reported that human-altered coastal habitats characterized by abundant shelters, abundant food and absence of predators, can act as settlement and growth areas for juveniles and adults of $O$. vulgaris. The availability of shelters can be a limiting factor for octopus distribution: several previous studies of different octopus species have described home choice and suggested characteristics used in the selection of hiding places (Mather, 1982; Altman, 1967; Katsanevakis and Verriopoulos, 2004). A direct-observation study in the Cies islands off the cost of Galicia (North West Spain) showed that the type of dens, substrate, abundance and availability of food were the main factors influencing octopus distribution. Juvenile $O$. vulgaris generally occupied holes sunk perpendicular into the substrate. Some of the existing and well-built dens occupied by older individuals may be used by successive generations of octopus (Guerra et al., 2014). A mark-recapture experiment in the Sardinian Sea revealed the significance of food and shelter availability (especially for females) for the migratory activity of $O$. vulgaris (Mereu et al., 2015). The type of shelter available seems to affect growth in captivity. Kwon et al. (2019) recently compared growth and survival rates of juveniles reared with shelters for groups of animals ("pipe shelters"), shelters for individuals ("tube shelters") and no shelter, during two experiments conducted in different seasons. Survival and growth rates were higher for the groups reared in individual shelters. The authors analysed stress marks in beaks and their results showed that the group reared with individual shelters was not affected by stress during the experiments. A significant influence of temperature on growth rates was also observed in the study.

O. vulgaris paralarval distribution in a time series of cross-shelf transects in $\mathrm{N}$ Spain showed paralarval abundance was associated with downwelling conditions i.e. abundance increased when shelf currents flowed polewards, water temperature was high and water column stability was low (Otero et al., 2016). Such conditions, the authors suggested, are likely to tend to favour coastal concentration of the paralarvae. However, in the same region, Roura et al. (2016) observed more abundant $O$. vulgaris paralarvae under strong upwelling intensity, also noting that the larvae tended to be more abundant in surface waters, though not significantly so. Perales-Raya et al. (2018) examined O. vulgaris paralarvae, including daily beak growth increments to obtain an accurate estimation of age, in wild specimens collected from the coast to the open ocean off NW Spain and Morocco. As the number of increments (age) increased with increasing distance offshore, this supported the hypothesis that $O$. vulgaris paralarvae leave the coastal area and develop in the open ocean, transported by upwelling 'filaments' (i.e. long narrow bodies of cold water protruding from an upwelling front into a warm oligotrophic ocean). Roura et al. (2019) subsequently used genetic evidence to examine dispersal strategies in various cephalopod species including $O$. vulgaris in two contrasting upwelling systems (Morocco and NW Iberia). Their results agreed with the idea that O. vulgaris displays a coastal-oceanic dispersal pattern. Low nucleotide and haplotype diversity was observed in $O$. vulgaris compared to other groups (Roura et al., 2019). All studies found that paralarval abundance increased at the end of the summer and autumn months.

\subsection{Life history}

There is still relatively little information available on $O$. vulgaris early life stages. However, some recent studies have contributed to fill this gap. Deryckere et al. (2020) showed that O. vulgaris embryos can develop without maternal care in artificially oxygenated seawater with a continuous strong flow rate and dim light. Several improvements in the tank system were applied to simulate the effect of maternal care. The system was modified to protect egg strings from air bubbles, additionally strings were attached to the lateral side of the tanks ensuring that they moved gently in the water and that eggs were continuously rubbing against each other, likely functioning as a natural cleaning system.

Observation of brooding female octopus in their natural habitat showed that hatching took place when water temperature increased to $\sim 20^{\circ} \mathrm{C}$. During hatching, the females temporarily opened the den entrance to provide a way out for small groups of hatchlings (Hernández-Urcera et al., 2014). Newly hatched paralarvae use inner yolk until they have learned to catch prey. The intensity of yolk utilization is highly influenced by the ambient temperature. Lower temperatures 
reduce the energy requirements and enhance inner yolk accumulation, thus allow hatchlings to survive without feeding for a longer period (Nande et al., 2017). Unsurprisingly, temperature also has a marked effect on the duration of embryonic development of this species: at $18{ }^{\circ} \mathrm{C}$, embryonic development lasts 40 days whereas at $14^{\circ} \mathrm{C}$ it lasts 67 days (Nande et al., 2018).

Daily growth increments in beaks from the full ontogenetic range, including early stages, of $O$. vulgaris have been validated by Perales-Raya et al. (2014 a, b) and subsequently used for age estimation (Garrido et al., 2016), as well as to identify potential rearing stress in captive paralarvae (Franco-Santos et al., 2016). Perales-Raya et al. (2018) estimated ages of wild and captive $O$. vulgaris paralarvae, with their experiments in captivity showing that increment deposition was not affected by diet but was influenced by rearing temperature. Daily increment deposition was confirmed at $21{ }^{\circ} \mathrm{C}$ (optimal rearing conditions) but $<1$ increment per day was recorded at $14^{\circ} \mathrm{C}$. At this "adverse" rearing temperature, the authors observed slower but more variable growth of beak and body weight, which could result in slower increment deposition or merging of increments. Growth of embryos is adversely affected by higher than optimal temperature. Armelloni et al. (2020) described the effect of temperature on embryonic beak growth and at warm rearing temperatures $\left(23^{\circ} \mathrm{C}\right)$, the beak size was significantly smaller and more variable than in embryos reared at 16,19 and $21^{\circ} \mathrm{C}$. Armelloni et al. (2020) also validated the age of first increment formation in the rostrum surface of the beak, when the pigmented dentition erupts. The thin line which develops at the base of the dentition, identified as "day 0 " in the rostrum surface, is observed only when embryos empty the outer yolk sac (considered the optimal moment for hatching in normal conditions). The presence of some increments in the lateral walls of the beak before hatching was also noted.

Recent biological studies in the Eastern Mediterranean (Çetinörge and Önsoy, 2018) showed that the potential fecundities of $O$. vulgaris females were significantly correlated with mantle lengths, whereas in males, the relationship with mantle length was stronger for length of spermatophores than for their number. The gonadosomatic index in females peaked in March, suggesting late winter and early spring as the spawning season in the region.

Finally, the availability of an $O$. vulgaris genome (Zarrella et al., 2019) offers new opportunities for understanding the genetic determinants of life history traits and the trade-offs associated with them. García-Fernández et al. (2019) carried out a transcriptomic and proteomic study on the effect of culture conditions on $O$. vulgaris paralarvae (see section 3.6 below for details). This study also recorded higher growth of octopus paralarvae at $19{ }^{\circ} \mathrm{C}$ than at $15^{\circ} \mathrm{C}$, possibly due to metabolic rate (and feeding intensity) being higher at the higher temperature.

\subsection{Ecology}

Trophic relationships of different ontogenetic stages of $O$. vulgaris were addressed in several studies. $O$. vulgaris paralarvae appear to be highly selective predators, eating mainly decapods independently of the zooplankton communities they inhabit (Roura et al., 2017), although seasonal and spatial variability in the diet has also been reported (Olmos-Pérez et al., 2017). A study on stomach contents of post-settlement wild $O$. vulgaris from Atlantic and Mediterranean coasts revealed that bivalve molluscs were the most frequently occurring prey group, followed by brachyuran crustaceans and teleosts. Bivalves dominated the diet of larger octopus, but in smaller individuals, crustacean prey dominated. No seasonal or sex-related variation in diet was observed (Ajana et al., 2018).

\subsection{Fishery management and conservation}

In Europe, the common octopus is mostly targeted by fisheries in Iberian Peninsula and Mediterranean waters where cephalopods have long been important for artisanal fisheries. Fishers' preferences for management in the Portuguese artisanal fishery of $O$. vulgaris (using traps and pots) were analysed by Silva et al. (2019), conducting questionnaires in 13 fishing ports of Southern Portugal. Their results indicate that octopus fishers have reasonable biological knowledge of the resource and are not satisfied with the current management of the fishery: their preferred management measure is fishery closure and they welcome a participatory co-management-based approach (see also Rangel et al. (2019)). The demand for the establishment of a close season in the Algarve octopus fishery arose from participatory workshops involving fishers, as reported by Sonderblohm et al. (2017). Bañón et al. (2018) highlighted a need for more flexible and adaptative management measures that take into account spatio-temporal variability in effort and decisions on fishing strategies in the small-scale trap fishery targeting common octopus in the north-west coast of Spain, proposing a move to a hybrid system incorporating both effort and catch controls.

\subsection{Culture and welfare}

Analysis of diet nutritional composition indicated that diets typically supplied to cultured Octopus paralarvae do not fulfil their fatty acid requirements (Garrido et al., 2016). Artemia metanauplii (the most common prey used for rearing paralarvae) may not be the most appropriate vehicle to provide fatty acids such as docosahexaenoic acid (Reis et al., 2019). Adding zoeae to an Artemia-based diet, thus improving the balance of lipid content in the diet, was associated with changes in the gene expression profile in O. vulgaris paralarvae (García-Fernández et al., 2019). The gene encoding for lysophospholipid acyltransferase showed reduced expression in paralarvae fed on only Artemia. Deficiencies in the activity of this gene have been associated with intestinal damage, which could also explain the poor growth performance paralarvae fed on Artemia. The study also provided the first evidence that a diet consisting exclusively of Artemia reduces glucose synthesis.

In captivity, comparison of live prey and re-constructed pelleted diets, based on different species of fish, squid and crab, revealed that both types of food can promote equal growth and survival of octopus juveniles. Thus, dry, pelleted meals could be used in aquaculture, although optimization is needed as assimilation efficiency is still lower than for natural diets (Querol et al., 2015; Rodríguez-González et al., 2015). Experiments revealed that enrichment of live prey by marine phospholipids has a beneficial effect on paralarval growth and improves survival rate (Garrido et al., 2018; Morales et al., 2017; Roo et al., 2017).

The nutritional status of adult $O$. vulgaris fed with semi-moist feeds in captivity was studied by Aliaga Taberner (2019), as a starting point for development of more economically and ecologically sustainable commercial feeds for the species. A control feed formulated with marine protein sources was compared with feeds based on vegetable protein concentrates (soy or pea) or blood meal. The best growth results came from the control group, followed by the octopuses fed with soy, peas and, last, the group fed with blood meal. The author suggested that feeds containing a mixture of marine and alternative protein sources could increase acceptability and lead to achievement of growth rates comparable to those achieved with diets based on marine protein sources.

Significant advances in paralarval survival under culture conditions have permitted animals to reach the benthic stage, in both $O$. vulgaris (Tur et al., 2019) and O. sinensis (Dan et al., 2018). In O. vulgaris the survival rates reached by Tur et al. (2019) using amphipod prey were $>90 \%$ at 40 days after hatching (DAH), $>80 \%$ at $50 \mathrm{DAH}$ and $>65 \%$ at $60 \mathrm{DAH}$. In $O$. sinensis the survival rate from hatching to benthic stage (25 DAH) was $51.6 \%$ using an upwelling rearing system (Dan et al., 2018). Unlike a traditional rearing system where the air is distributed from the surface to the bottom, in the upwelling rearing system, air comes from the center of the tank's bottom. Because of this, water flow is directed from the bottom to the surface, supporting the swimming capabilities of paralarvae. 


\subsection{Other studies}

The health risk to humans from heavy metals present in octopus fished along Mediterranean coast of Morocco was evaluated by Karim et al. (2019), who concluded that levels in edible parts of the animals would cause no health problems for consumers.

In the field of European cephalopod diseases, diagnoses, and pathologies, the recently published Handbook of Pathogens and Diseases in Cephalopods (Gestal et al., 2019) is an essential reference.

\section{Eledone spp}

\subsection{Introduction}

Eledone cirrhosa (curled or horned octopus) and E. moschata (musky octopus) are the two other species of superfamily Octopodoidea fished commercially in the European waters but reported landings of both species are much lower than those of $O$. vulgaris. Sale prices are also generally lower for Eledone although in Italy the price of E. cirrhosa in summer tends to exceed that of Octopus vulgaris ${ }^{3}$ The lower commercial value and the absence of interest in culture of these species is reflected in the lower number of published papers. Jereb et al. (2015) highlighted five priority fields for future research on E. cirrhosa and E. moschata, namely: (1) spawning sites, (2) fecundity, (3) studies on early life stages, (4) age increment reading of beaks and stylets, and (5) genetic studies for stock identification. However, the majority of recent publications on these species focused on other aspects of biology, ecology and exploitation. Only one study (Regueira et al., 2015) addresses age estimation of $E$. cirrhosa.

Thus, to a great extent the priorities for future research remain the same as they were in 2015. In addition, as these octopuses may play a significant role in trophic webs, studies on predator-prey interactions of E. cirrhosa and E. moschata are of interest.

\subsection{Environmental effects, distribution and abundance}

Eledone cirrhosa has a relatively high abundance in the North West Mediterranean Sea, its biomass being around half that of $O$. vulgaris (DeLaHoz et al., 2018). Gajić et al. (2014) reported the first record of E. moschata in Neum Bay (Adriatic Sea) in the 21 st century. They found three adult individuals in very shallow waters ( $<1 \mathrm{~m}$ depth), which is shallower than the known depth range of the species (from 10 to $300 \mathrm{~m}$ ), reported in Jereb et al. (2014).

In the North Atlantic (North West Iberian waters), the largest individuals of $E$. cirrhosa were recorded in summer and, in general body size, increased with increasing water depth. Highest abundances were recorded in autumn and at intermediate depths (100-200 m), when new recruits were present in high abundance (Regueira et al., 2014). Results were consistent with a migration to deeper waters throughout the summer (i.e. in the reproductive period). Abundance also varied consistently with latitude, which the authors interpret as evidence of the importance of photoperiod, due to its role in determining the timing of maturation (as previously suggested by Regueira et al., 2013).

The influence of environmental variables on the distribution of four commercial cephalopods, including Eledone spp., in the Central Mediterranean Sea was investigated by Lauria et al. (2016), who found that depth, seafloor morphology, chlorophyll-a concentration, sea surface temperature and salinity were the main predictors of cephalopod habitat suitability. Their results for E. moschata and E. cirrhosa suggest some degree of similarity in their habitat preferences, with an affinity for soft bottoms, areas of high productivity and SST ranging from 20 to $22{ }^{\circ} \mathrm{C}$. However, E. moschata shows a preference for shallower waters and

\footnotetext{
3 https://www.eumofa.eu/documents/20178/393194/PTAT+Octopus_EN. pdf
}

habitat suitability maps indicate distinct distributions, which the authors suggest are probably the result of adaptation to availability of prey and competition for space.

Puerta et al. (2014a; 2015) suggested that inter-annual changes in the spatial distribution of two of the main cephalopod species harvested in the Western Mediterranean Sea (Illex coindetii and E. cirrhosa) were attributable to the same environmental variables but the response in each species was different due to their different life history strategies. Puerta et al. (2014a) found that small-sized individuals of both species often occur in shallow waters, while adults occur in deeper habitats. The distribution of $E$. cirrhosa was mainly affected by conditions during the previous winter, which is in accordance with previous studies reporting lagged-time responses to environmental drivers in both this species and $O$. vulgaris. The occurrence of $E$. cirrhosa was determined by the presence of productive areas, while population density was also affected by chlorophyll concentration and SST, although these environmental relationships varied across the region (Puerta et al., 2015).

\subsection{Life history}

Reproductive biology of Eledone spp. in Atlantic Iberian waters and Tunisian waters was described by Regueira et al. (2013) and Rjeibi et al. (2013), respectively. Regueira et al. (2018) reported that, in captivity, females of $E$. cirrhosa spawn inside a shelter, within which they remain during egg development, and block the entrance with stones and other materials found near the burrow.

The age of $E$. cirrhosa was estimated using stylets by Regueira et al. (2015), who found that lifespan could reach 17 months in the North Atlantic (North West Iberian waters), with instantaneous growth rates ranging from $0.03 \%$ to $2.17 \%$ of body weight per day. In the Adriatic Sea, the beaks of female $E$. cirrhosa show a higher rate of growth (relative to body size) than in males (Ikica et al., 2014). In addition, four (beak) pigmentation stages were established for the reconstruction of individual size through the comparison of mantle length, body weight and beak characteristics. They were more easily identified in lower beaks, although the authors concluded that pigmentation stages could not be reliably used to estimate an animal's size.

Weight-length relationships for E. cirrhosa and E. moschata in South West Iberian waters (Gulf of Cádiz) were similar, although the scaling exponent $b$ was lower in $E$. cirrhosa $(b=2.34)$ than in $E$. moschata ( $b=2.70$ ) (Torres et al., 2017).

\subsection{Ecology}

Stomach contents of $E$. cirrhosa in Atlantic Iberian waters consisted mostly of crustaceans, teleost fish, echinoderms, molluscs and polychaetes. Diet composition varied significantly with season, fishing ground and maturity stage (Regueira et al., 2017). According to stomach contents analysis conducted by Şen and Akyol (2014), E. moschata in the Aegean Sea fed principally on crustaceans.

Spatial overlap between E. cirrhosa and the catshark Scyliorhinus canicula was reported by Puerta et al. (2016) in the Western Mediterranean, a finding which may reflect dietary overlap, but the degree of overlap varies over time as the abundance of Eledone varies, highlighting the necessity of further studies on species interactions.

Based on 18S rDNA sequences, the dicyemid mesozoa Dicyemennea eledones, a parasite of $E$. cirrhosa in the Bay of Biscay and Gulf of Tunis, was redescribed. New data on $18 \mathrm{~S}$ rDNA sequences allows reliable identification of $D$. eledones because it differs from other dicyemid species (Souidenne et al., 2016).

\subsection{Other studies}

Barragán-Méndez et al. (2019) analysed physiological responses to capture (in trawls) of octopuses, including both Eledone species. They found evidence of the immune system being compromised but also noted 
that recovery occurred after $24 \mathrm{~h}$. The authors suggest that the various stress biomarkers studied could provide useful tools to evaluate welfare of these species under culture conditions.

Health risks to humans from eating these species were evaluated by by Roldán-Wong et al. (2018), who concluded that, even when Eledone is taken from contaminated sites, the consumption of muscle tissues is not an issue of concern. However, due to high Cd levels in digestive gland, consumption of this tissue should be more carefully monitored to avoid health problems.

\section{Sepia officinalis}

\subsection{Introduction}

Sepia officinalis is the best known representative of the genus Sepia, and is widely distributed across European waters. Among European sepiids it is the most heavily exploited species with total annual catches reaching approximately 40,000 $\mathrm{t}$ (Jereb et al., 2015).

In the most recent review (Jereb et al., 2015), the following fields of study were highlighted as important future research directions of common cuttlefish (Sepia officinalis): (1) separation of stocks, (2) studies on trace element and isotope composition of hard structures, (3) development of age estimation methods, and (4) investigation of climate change impacts on cuttlefish populations. Of these, three fields have received most attention in the past seven years, specifically: the composition of hard structures, development of age estimation methods and environmental impacts (including climate change) on cuttlefish. Significant advances in stock assessment were also reported.

Although this is one of the best known European cephalopods, especially in relation to biology and ecology, further studies on climate change impacts and the effects of pollution on cuttlefish are still needed. Studies on the effects of coastal waste (including plastics, heavy metals, oil industry waste) and sound/light pollution on cuttlefish are of great interest. Monitoring the status of exploited cuttlefish stocks remains essential due to their considerable commercial value. Establishment of marine protected areas (MPAs) could be considered as an option to protect spawning and nursery grounds of cuttlefish stocks, along with the introduction of catch or effort limits where the exploitation rate is high.

As with many cephalopod species, recent studies show that Sepia beaks are suitable for use in age determination but additional studies (e. g. validation of periodicity of increment deposition, time elapsed before the first increment is formed, investigation of erosion of the tip, etc.) are needed (Lishchenko et al., 2018aa). Studies on the spatial distribution of cuttlefish populations are also needed, as is knowledge about the level of mixing between neighbouring stocks, although the great potential of electronic tags in this field should be noted (Wearmouth et al., 2013). Moreover, the latter could provide essential information on environmental conditions experienced during the tag-bearing period. Deeper understanding of population structure and the environmental conditions experienced at different life stages could also derive from morphometric analysis of hard structures, trace-element composition analysis and molecular methods (Fang et al., 2014a, b, 2016a, b; Green et al., 2015; Lishchenko et al., 2017; McKeown et al., 2015).

\subsection{Environmental effects, distribution and abundance}

The impact of climate change on distribution and abundance of cuttlefish was the second most popular field of study (see Dorey et al., 2013; Giansante et al., 2014; Keller et al., 2014; Xavier et al., 2016). Dorey et al. (2013) showed how increasing ocean acidification could affect the development of cuttlefish. Although growth rate was apparently not affected by lower $\mathrm{pH}$, incorporation of ${ }^{45} \mathrm{Ca}$ (i.e. a radiotracer) into cuttlebones significantly increased with increasing acidification. The authors stated that "a decrease in seawater $\mathrm{pH}$ by $0.25-0.50$ units, as expected, on average, by the end of this century in global oceans, would increase the accumulation of calcium in the internal calcareous structure by $17-80 \%$ in embryonic and juvenile cuttlefish, respectively", which would change both buoyancy and sensitivity to pressure. Juvenile cuttlefish in acidified environments experience lower growth and increased calcification of their internal shell, developing denser cuttlebone laminae in shorter cuttlebones (Sigwart et al., 2016). Reductions in dissolved oxygen associated with warming would also be expected to have an impact on cuttlefish. Capaz et al. (2017) who found that exposure of cuttlefish for $1 \mathrm{~h}$ to a dissolved oxygen level of $50 \%$ saturation leads to an $85 \%$ increase in ventilation rate, nevertheless resulting in a $37 \%$ reduction in oxygen consumption.

The spatial distribution and abundance of a common cuttlefish were addressed in a series of survey-based studies. Results from surveys in the Alboran Sea and Catalan Sea (Ciércoles et al., 2018; DeLaHoz et al., 2018) and in the Mediterranean Sea in general (Quetglas et al., 2019) indicate that $S$. officinalis inhabits shallower and more inshore waters than S. elegans and S. orbignyana. In the Catalan Sea, S. officinalis was generally the least abundant cuttlefish species except in winter, when it was most abundant and its abundance reached a peak in the $30-100 \mathrm{~m}$ depth range (DeLaHoz et al., 2018).

Migration in Mediterranean populations of cuttlefish is affected by increasing annual SST but, although a shift in cuttlefish population dynamics was seen in the early 1980s, no lasting effect of climate change on cuttlefish populations has been reported to date (Giansante et al., 2014; Keller et al., 2014). Xavier et al. (2016) discussed possible long-term effects of climate change on the distribution of $S$. officinalis, noting that temperature rises to $9.5^{\circ} \mathrm{C}$ in the North Atlantic could lead to an expansion of the range of $S$. officinalis to reach the East American coast, potentially leading to complete alteration of the trophic web in coastal marine ecosystems there.

In a study on isotopic variation in the cuttlebones of three cuttlefish species, Dance et al. (2014) showed that the values of $\delta^{13} \mathrm{C}$ and $\delta^{18} \mathrm{O}$ increased from the cuttlebone core to its edge, which may be a consequence of ontogenetic migration of the animals from nearshore nurseries (lower seawater $\delta^{13} \mathrm{C}$ and $\delta^{18} \mathrm{O}$ values) to offshore overwintering habitats (higher seawater $\delta^{13} \mathrm{C}$ and $\delta^{18} \mathrm{O}$ values). Values of $\delta^{13} \mathrm{C}$ and $\delta^{18} \mathrm{O}$ were lower in $S$. officinalis compared to $S$. elegans and $S$. orbignyana, reflecting interspecific differences in spawning behaviour and distribution (i.e. S. officinalis tends to spawn closer to the shore than other two species).

Information on distribution and movements of cuttlefish can also be obtained more directly by applying long-term electronic tags such as ones which were developed by Wearmouth et al. (2013). Tests showed that these electronic tags did not significantly affect cuttlefish natural behaviour and could be used to monitor their migrations.

$S$. officinalis is a widely-distributed and highly sensitive bioindicator of pollution, as shown by biomarker responses to a range of pollutants found in seabed sediments (Rodrigo et al., 2013), as well as several studies looking at effects of contaminants on behaviour, growth and mortality. Trace element concentrations and their effects on juvenile cuttlefish have been investigated in several recent studies (Raimundo et al., 2014; Le Pabic et al., 2014, 2015; Lacoue-Labarthe et al., 2016; Rjeibi et al., 2014). Trace elements are consistently accumulated in the tissues of cuttlefish, with highest levels found in the digestive gland and lowest levels in the muscles (Rjeibi et al., 2014; Rodrigo and Costa, 2017). Rodrigo and Costa (2017) described the role of the digestive gland in the detoxification process while Penicaud et al. (2017) provide information on the subcellular locations of trace elements and rates of accumulation and detoxification. High concentrations of dissolved $\mathrm{Zn}$ in seawater lead to reduced growth (at a concentration of $108 \mu \mathrm{g}^{-1}$ ) and increased mortality (at $185-230 \mu \mathrm{g}^{-1}$ ) as well as effects on digestion, behaviour and immunity (Le Pabic et al., 2014, 2015; Lacoue-Labarthe et al., 2016). Cuttlefish have higher concentrations of $\mathrm{Hg}$ in their tissues than do other benthic cephalopods, as seen in Augusta Bay, a highly contaminated area in the Central Mediterranean (Signa et al., 2017). According to a review by Mouritsen and Styrbæk (2018), cuttlefish flesh 
contains more arsenic than other major cephalopod taxa. Although most of this arsenic is in an organic form, cuttlefish is not considered dangerous for consumption (Mouritsen and Styrbæk, 2018). According to a study in Northern Tunisia (Abidli et al., 2019), S. officinalis accumulate a much lower amount of microplastics (MP) than bivalves and some gastropods, even if the total amount of MP is still quite high (up to $700 \mathrm{M} \mathrm{P}$ units $/ \mathrm{kg}$ of wet weight). Again, since most of the MP items were found in the digestive gland, any associated risks to consumers would be reduced by removing this organ prior to consumption. Finally, antidepressants released into the environment can affect the camouflage patterns and hunting behaviour of cuttlefish, leading to lower rates of survival (Di Poi et al., 2013, 2014; Lacoue-Labarthe et al., 2016).

Solé et al. (2017) showed that exposure to underwater noise in S. officinalis' natural habitat can damage their statocysts, as revealed using scanning electron microscopy, thus confirming the relevance of previous laboratory-based experiments on several species of cephalopod (e.g., Solé et al., 2013a, b). An experimental study on cuttlefish reactions to different levels and frequencies of sound (Samson et al., 2014) showed that they demonstrate escape responses to frequencies from 80 to $300 \mathrm{~Hz}$ at sound levels above $140 \mathrm{~dB}$. These findings could be used for assessment of impacts of sound pollution on cuttlefish and serve as a basis for examining the increasing impact of ocean noise in other cephalopod species.

\subsection{Life history}

The first experiments in captivity to validate the periodicity of deposition of growth increments in cuttlefish beaks showed that beaks could serve as a simple and reliable tool for $S$. officinalis age estimation (Lishchenko et al., 2018aa). This method was subsequently applied to analyse age structure in wild cuttlefish from the Gulf of Cadiz, revealing a single pronounced spawning peak at the end of spring-early summer, with the presence of small-sized and large-sized individuals in the same aggregation. Cohort growth was apparently determined by the combined individually experienced ambient temperature, resulting in higher growth rates in autumn than in spring (Lishchenko et al., 2018b).

A flexible spawning strategy typical of cephalopods was seen by Lin et al. (2019b), who reported that mature or spawning female S. officinalis sampled in July-August off Mauritania showed a wide range of body sizes (148-270 mm). Fecundity increased with body size and it was estimated that females could release 770-1966 viable eggs during the spawning season. The size of the mature females reported in this study is consistent with previous reports for $S$. officinalis off the African coast (see Jereb et al., 2015).

Common cuttlefish in the English Channel have the largest eggs recorded in this species $(8.5-12.2 \mathrm{~mm}$ in length, $221-533 \mathrm{mg}$ in weight). The potential fecundity was estimated to be 3,200-13,000 eggs and actual fecundity up to 3000 eggs. The size of post-ovulatory follicles seen in June was similar to the size recorded in March, suggesting that the sampled animals had a similar spawning history, that individual females have relatively short spawning periods, and that the length of the reproductive season reflects individual variability in the timing of spawning (Laptikhovsky et al., 2019).

Weight-length relationships were studied in common cuttlefish from Southern Portugal (Vasconcelos et al., 2018). A slower relative growth rate in weight than in length (scaling exponent $\mathrm{b}<3$ ) was reported, which is a common feature of short-lived species (Torres et al., 2017). Vasconcelos et al. (2018) concluded that this feature is the result of high feeding rate and high food conversion efficiency. A broader cuttlebone and greater energy investment in the development of the reproductive organs were assumed to be the main cause for higher relative weight gain in females $(b=2.696)$ than in males $(b=2.588)$.

\subsection{Fishery management and conservation}

Several studies on fisheries targeting $S$. officinalis addressed major current issues. A study on IUU (illegal, unregulated and unreported) fishing in the Gulf of Sicily (Falautano et al., 2018) showed that the number of vessels engaged in IUU fishing is only slightly lower than the number of vessels fishing legally. CPUE (catch per unit effort) in the legal fishery is around twice that in the IUU fishery. Thus, IUU fishing must be considered in fishery management, even if it is impossible to estimate the total amount of cuttlefish caught by IUU fishers. A study on the efficiency of modified trammel nets showed that application of a "guarding net" (the additional mesh attached to the footrope and the trammel net) and an LED light system leads to a significant increase in cuttlefish catches (by up to $95 \%$ ) and a decrease in discards (6\% versus $19 \%$ in unmodified trammel nets) (Martínez-Baños and Maynou, 2018). Pereira et al. (2019) estimated the environmental and socio-economic impact of an artisanal small-scale trap fishery for cuttlefish, showing that this has both a relatively low impact on the stock due to low levels of discards, and high economic value, as animals are sold fresh and undamaged; providing indications that artisanal trap fisheries can be both profitable and sustainable.

A two-stage biomass model was developed for assessment of English Channel cuttlefish stocks by Gras et al. (2014) and was subsequently updated by Alemany et al. (2015, 2017). The model allows estimation of biomass, not only of the exploited part of stock but also an unexploited winter biomass, and provides a potentially useful tool to allow detection of excessive stock depletion. Palas et al. (2017) investigated fishing pressure due to the recreational fishery for cuttlefish in the Ría de Vigo area. The fleet exploits an area of approximately $30 \mathrm{~km}^{2}$ and contributes up to $11 \%$ of catches of this species in the area. The authors thus proposed that marine recreational fisheries should be considered in fishery regulations. A study on the common cuttlefish in the Adriatic Sea (Mion et al., 2014) suggested that extension of a summer ban for the trawling fishery could allow a higher portion of the stock to reach a commercial size. On the other hand, it was found that only $31 \%$ of undersized cuttlefish captured in the English Channel were still alive by the time they reached the sorting table and release of these animals may thus be of little benefit to the stock (Revill et al., 2015). This indicates the necessity of developing methods to reduce the capture of small cuttlefish to ensure more sustainable exploitation. It is possible that the solution recommended for the Adriatic Sea stock, i.e. a seasonal closure, could benefit the English Channel cuttlefish stock and fishery. Mortality of eggs deposited on fishing traps also remains a cause for concern (Bloor et al., 2013). In the Adriatic Sea, the use of inexpensive and easily detachable egg receptors was suggested, as their deployment allowed recovery of $23.7 \%$ of laid eggs (Melli et al., 2014). The recent study by Davies and Nelson (2018) confirmed the efficacy of egg receptors within fishing traps used to target $S$. officinalis in the English Channel. Authors found that $\sim 50 \%$ of eggs were laid on these pieces of detachable rope.

The utility of marine protected areas for cuttlefish was assessed by Abecasis et al. (2013), who showed that marked cuttlefish showed low site fidelity and undertook large movements. They concluded that small MPAs are not effective for long-term protection of highly migratory cephalopods such as cuttlefish and thus are unlikely to benefit the stocks. Note however, that the most likely value of such MPAs for cuttlefish would be to protect inshore spawning habitat.

\subsection{Culture and welfare}

Protocols for small-scale cuttlefish culture were described by Panetta et al. (2017), who reported on methodology for maintaining a small cuttlefish colony for research purposes. This approach could provide a platform for insights to essential fishery biological traits of cuttlefish. A study into the effects of artificial incubation in cuttlefish (O'Brien et al., 2017b) showed this type of incubation to be no different from natural incubation in relation to hatchling size, defence and predation behaviour. Thus, eggs which would otherwise be lost as fishery bycatch could be reared artificially.

A study on seasonal changes in locomotor activity showed that 
cuttlefish show dualistic behaviour, being more active at night during summer and autumn and more active during the day in winter (Oliveira et al., 2017). These findings are potentially relevant for both aquaculture and fisheries.

Safi et al. (2018) used digestive enzyme ratios as an indicator of digestive gland maturation in cuttlefish early life stages. According to the study, enzyme ratios precisely reflect both yolk content and digestive gland development. This approach could serve as a tool for determination of cuttlefish growth performance, for example in aquaculture.

Finally, welfare needs for cuttlefish rearing were addressed by Sykes et al. (2017). Methods for sex and maturity determination, tagging, and DNA sample collection were tested in relation to pain, suffering, distress and lasting, harmful effects experienced. It was concluded that the use of an endoscope, visual implant elastomer and swabbing could provide all necessary information without causing negative effects.

\subsection{Other studies}

Martins et al. (2018) showed that at least ten different invertebrate species (Bolinus brandaris, Cancer pagurus, Dardanus arrosor, Homarus gammarus, Callinectes sapidus, Squilla mantis, Echinus melo, Cidaris sp., Paracentrotus lividus, Astropecten aranciacus) feed on cuttlefish egg masses. The authors suggest that the invasive blue crab Callinectes sapidus should be considered as a new threat for cuttlefish in North East Atlantic waters.

A study on the impact of maternal and embryonic stress showed that both natural stressors (such as predator presence) and artificial stressors (in this case, light) affect juvenile cuttlefish hunting behaviour (O'Brien et al., 2017a).

\section{Sepia elegans and S. orbignyana}

The elegant cuttlefish Sepia elegans and the pink cuttlefish S. orbignyana are small cuttlefish species (maximum DML of $9 \mathrm{~cm}$ and $12 \mathrm{~cm}$ respectively) distributed across deep waters (up to $580 \mathrm{~m}$ depth) of the North East Atlantic and Mediterranean (Jereb et al., 2015). They are of relatively low interest for fisheries, despite their high abundance in some parts of the range. Jereb et al. (2015) recognised several fields of research as important for the understanding of the biology of these species, including (1) clarification of their systematic position, (2) an improvement in reporting of fishery landings (i.e., reporting at the species level), and (3) studies on distribution and life history. Among these, there has been some progress only in the third field. As the total amount of published articles concerning these species are very low (only 9 articles in which these species were at least mentioned were published within last seven years) this section is not divided into subsections. As for the remaining knowledge gaps, clarification of the taxonomic position of both species remains important. Moreover, similarly to $S$. officinalis, stock structure and range of the populations should be studied in order to allow development of fisheries strategies for all three species. Finally, the development of a simple guide or tool for identification, thus allowing separation of data on landings of Sepia spp. is of a great interest.

These two species have been markedly less studied in recent years than $S$. officinalis. Of three studies on $S$. elegans published during 2013-2019, a large-scale study of its reproductive biology in the East Mediterranean revealed a number of differences from the West Mediterranean and Atlantic Ocean (Salman, 2015a). Dance et al. (2014) confirmed differences in the spawning and nursery ground locations of the three Mediterranean cuttlefish species ( $S$. officinalis, S. elegans and $S$. orbignyana) based on stable isotope analysis of cuttlebone. The study showed that $S$. officinalis spawns in nearshore areas and its juveniles inhabit coastal areas where they are likely to be exposed to higher temperatures and variable salinity. On the other hand, S. elegans and $S$. orbignyana use offshore nurseries which are less affected by coastal processes. Finally, a study on the composition of trawling fleet catches in the South East Mediterranean in 2014-2015 (Rizkalla et al., 2016) showed that $S$. elegans is the sole representative of the family occurring in these catches.

Spatial, depth-related and temporal distributions of $S$. elegans and $S$. orbignyana have been described in several studies of demersal fish and cephalopod communities, generally showing that the latter species occurs in deeper water than the former. In the Alboran Sea, S. elegans is more abundant on the continental part of the shelf, while in the island area at these depths $(30-200 \mathrm{~m}) \mathrm{S}$. orbignyana is more common. At greater depths, only $S$. orbignyana is present (Ciércoles et al., 2018). In the Catalan Sea, $S$. elegans and $S$. orbignyana were generally the most abundant cuttlefish species, with the former most abundant at $30-100 \mathrm{~m}$ and the latter at $200-400 \mathrm{~m}$. However, in winter, S. officinalis was more abundant than either of these species (DeLaHoz et al., 2018). Cuttlefish distribution across the whole Mediterranean Sea was described by Quetglas et al. (2019) who showed that S. elegans is widely distributed across bioregions in the Mediterranean, reaching the highest abundance on the continental shelf area, while $S$. orbignyana is the most common cuttlefish in the upper slope zone. It should be noted that these studies are valuable not only in terms of providing basic information on species distribution but also to reveal environmental and anthropogenic impacts on cephalopods. DeLaHoz et al. (2018) indicated that cephalopods, in general, preferred muddy substrates but, even in their preferred environment, cuttlefishes were less abundant than squids. Quetglas et al. (2019) discussed the impacts of different fishing methods on sepiids and suggested that the abundance of $S$. elegans and $S$. orbignyana was highest in the Aegean Sea because in this area these species are fished by small-scale trap-based artisanal fleets, which have a lesser impact both on targeted species and the habitat than other fishing methods.

Dursun et al. (2013) studied the impact of environmental conditions in the Eastern Mediterranean, along with some aspects of reproductive biology of the species. They showed that $S$. orbignyana displays 'Mediterranean nanism' (or dwarfism), i.e. these animals attain maturity at small sizes. Examination of gonads showed that pink cuttlefish in this area spawn all year round and are more r-strategist than elsewhere in their range, which may be a consequence of the impact of environmental conditions. In the Central Mediterranean, this species presents less pronounced r-strategist traits, reaching maturity at a smaller size and having a much lower fecundity (Šifner et al., 2018). The latter study also shows that, at least in the Adriatic Sea, $S$. orbignyana has group-synchronous ovulation and the species is most probably an intermittent terminal spawner. It was found that weight-length relationships of both sexes exhibit slower relative growth in weight than in length ( $b=2.46$ in males and $b=2.62$ in females), which corresponds to the growth patterns seen in the Gulf of Cadiz, although the scaling exponent $b$ reaches only 2.38 in the latter case (Torres et al., 2017).

\section{Sepietta oweniana}

\subsection{Introduction}

Common bobtail squid, Sepietta oweniana is a relatively small sepiolid species widely distributed across the ICES areas and adjacent waters (Jereb et al., 2015). This species is considered a 'generalist' within the Mediterranean (Šifner et al., 2015), being abundant in most survey tows and at most depth strata (Quetglas et al., 2019). Also distributed throughout the North East Atlantic, this species has recently been recorded down to $1000 \mathrm{~m}$ in Atlantic waters off West Africa (Rocha and Cheikh, 2015). Among the sepiolids, S. oweniana has the greatest commercial value and is exploited as a bycatch species. This species is commonly sold in Mediterranean markets and is valued as a delicacy in areas such as Southern Sicily (Jereb et al., 2015).

In their review, Jereb et al. (2015) indicated two particular fields as being essential for an understanding of species biology in $S$. oweniana: (1) separation of stocks and cohorts and (2) development of better 
identification tools allowing fishery landings to be separated by species. A number of studies were published in the review period, but the essential fields of study indicated by Jereb et al. (2015) remain relatively poorly addressed. Research gaps remain in relation to fisheries, in particular, landings data identified to species are still needed, and there is also a need to assess $S$. oweniana abundance.

\subsection{Environmental effects, distribution and abundance}

Golikov et al. (2014) and Xavier et al. (2018) report the first catches of $S$. oweniana in the Barents Sea, its presence there apparently driven by ongoing Arctic warming. However, the occurrence of this species in Arctic waters remains infrequent. By contrast, $S$. oweniana is the most abundant sepiolid species and indeed one of the most abundant cephalopod species in the West and Central Mediterranean (Quetglas et al., 2014; Sifner et al., 2015; DeLaHoz et al., 2018), where it is widely distributed across different areas and water depths (Keller et al., 2017a; Quetglas et al., 2019). Diel patterns of abundance are apparent however, with higher abundance closest to the seafloor of the continental shelf in daytime hauls and higher occurrence in surface or midwater depths during the night (Quetglas et al., 2014). S. oweniana is a member of the upper continental slope community whose abundance is positively correlated with winter SST (higher abundance in warmer winters) (Keller et al., 2017a). A strong seasonality exists in this species, with higher abundance in summer than in autumn in the West Mediterranean (Quetglas et al., 2014).

\subsection{Life history}

Lifespan is short in $S$. oweniana, 6-12 months, with individuals maturing by $4-5$ months of age after a planktonic-necktobenthic stage. Mature animals are found throughout the year in both the Atlantic and Mediterranean and spawning is year-round. S. oweniana is a multiple spawner that apparently continues to feed and grow during the spawning phase, but while seasonal spawning peaks do occur, these vary across the range (Jereb et al., 2015). Differentiation of sepiolid species in the field is difficult, requiring dissection, especially in females, as S. oweniana is easily confused with Sepietta neglecta, although the latter is a generally smaller species (Laptikhovsky and Ouréns, 2017). The need for dissection means that routine identification of sepiolids to species level in fishery landings remains unlikely. However, one study has shown that $18 \mathrm{~S}$ rDNA or COI could be used for species identification of sepiolids including $S$. oweniana in North Sea samples (Gebhardt and Knebelsberger, 2015). These authors recommended the use of COI rather than $18 \mathrm{~s}$ rDNA for species barcoding due to higher bootstrap support of species clusters and less amplification and sequencing failure for this gene. One study during the review period concerned the weight-length relationship of the bobtail squid inhabiting the Gulf of Cadiz area (Torres et al., 2017). S. oweniana has the lowest scaling exponent $(b=2.07)$ in its weight-length relationship among cephalopods inhabiting the study area.

\subsection{Ecology}

Common bobtail squid plays an important role in demersal ecosystems, feeding on a range of small-sized crustaceans as well as serving as prey for crustaceans, medium and large-sized fish and octopus, elasmobranchs and cetaceans. Stomach contents analysis of $S$. oweniana in the northern part of the range showed that individuals caught in the Barents Sea show unusual prey preferences, with fish being a major prey item, unlike other parts of the range (Golikov, 2014; Golikov et al., 2014). In terms of its role as prey, $S$. oweniana is eaten by demersal fish and elasmobranchs, including black anglerfish (Lophius budegassa) in the Catalan Sea (López et al., 2016) and small-spotted catshark (Scyliorhinus canicula) in the Aegean Sea (Kousteni et al., 2018). Targeting of S. oweniana by elasmobranchs in the Aegean was attributed to its demersal distribution in this area (Salman, 2015b). Predation on this species by black anglerfish was attributed to the nocturnal behaviour of $S$. oweniana; the white anglerfish (L. piscatorius) did not take S. oweniana, possibly due to it being more active during daylight hours (López et al., 2016). While some elasmobranchs in the East Mediterranean such as small spotted catshark preyed on $S$. oweniana, others such as longnose spurdog (Squalus blainville), velvet belly lanternshark (Etmopterus spinax) and blackmouth catshark (Galeus melastomus) did not eat this species (Bengil et al., 2019), despite the fact that $S$. oweniana was taken as prey in other parts of these predators' ranges (Jereb et al., 2015). Seals, dolphins and porpoises also appear to be important predators of this species (Jereb et al., 2015; Dede et al., 2016).

\section{Loligo vulgaris}

\subsection{Introduction}

As mentioned above, the European squid (Loligo vulgaris) is among the key cephalopod species for European fisheries (Jereb et al., 2015), hence the high interest in this species from a variety of researchers and stakeholders. Jereb et al. (2015) identified three priority topics for L. vulgaris: (1) studies on impacts of climate change, (2) investigation of trophic relationships and (3) the development of simple and reliable tools for identification of caught individuals. Climate change impact research appears to be progressing for $L$. vulgaris in North Sea ecosystems (van der Kooij et al., 2016; Engelhard et al., 2018) and off the Portuguese coast (Moreno et al., 2014b). There is little new information on trophic relationships except for the Mediterranean (Albo-Puigserver et al., 2016). Cefas have created the identification guide for shelf cephalopods in UK waters which serves as a tool for reliable identification of caught individuals, whether it be at sea or in the laboratory (Laptikhovsky and Ouréns, 2017). One of the more innovative outputs from recent research is the new 8-stage scale for L. vulgaris embryonic development (Feyjoo et al., 2016) which is non-invasive and can be used visually. From a fisheries perspective, there is a growing need to move to implement routine stock assessment and to quantify the amounts of L. vulgaris taken by recreational fishers (Pilar-Fonseca et al., 2014), particularly in areas where recreational landings contribute to a high proportion of the total landings and as such, may have implications for the accuracy of stock assessments. Other recent studies of $L$. vulgaris were predominantly from biomedical research. Perhaps this is indicative of a growing demand for $L$. vulgaris for reasons other than food.

\subsection{Environmental effects, distribution and abundance}

A study on the impacts of ocean warming and acidification (Rosa et al., 2014) revealed that ocean warming could lead to a significant decrease in embryo survival rate for $L$. vulgaris. According to this study, $2{ }^{\circ} \mathrm{C}$ warming and a decrease of $\mathrm{pH}$ by 0.5 caused a decrease in the survival rate of summer hatching embryos from approximately $94 \%$ to $47 \%$. Additionally, higher ambient temperature and hypercapnia (elevated $\mathrm{CO}_{2}$ levels in the blood) cause shortening of the embryonic development period, a higher percentage of abnormalities and a decrease in growth rate. Moreno et al. (2014b) suggested that temperature effects may be responsible for high inter-annual variation in juvenile abundance on the southern shelf of Portugal.

Engelhard et al. (2018) proposed that due to ocean warming, L. vulgaris and $L$. forbesii habitat suitability had increased around the UK since 1985 and will continue to do so until at least 2050 (median estimates of habitat suitability increase by $31 \%$ for $L$. vulgaris and $7 \%$ for L. forbesii). As their model implies that squid habitat suitability is increasing much more than that for finfish, they anticipate that more vessels will target squid, ultimately making the species more common in the diets of UK citizens. If consumption of 'calamari' derived from these species reaches higher levels than currently in Northern Europe, the need for management of fishing these stocks will increase. An expansion 
of the range of Loligo spp. in the North Sea associated with climate variables was reported by van der Kooij et al. (2016) while Laptikhovsky et al. (2018) report evidence of long-term variation in the timing of reproduction and distribution of $L$. vulgaris in the North Sea based on survey data.

\subsection{Life history}

Age determination is possible in both Loligo species using statoliths. Recent work suggests that growth increments in the eye lens can also be used. The number of increments counted in L. vulgaris (59-520) and in L. forbesii (51-543) was strongly related to mantle length and weight of the animals, with no statistical differences between the sexes. Assuming daily growth increments, $L$. vulgaris was estimated to have a life span of 17 months for males and 14 months for females, while $L$. forbesii had an estimated life span of 18 and 16.5 months for males and females respectively (Agus et al., 2018). These values are somewhat higher than the maximum lifespan suggested based on statoliths (see Jereb et al., 2015).

\subsection{Ecology}

A stable isotope study on trophic relationships of pelagic fish and squid in the Mediterranean (Albo-Puigserver et al., 2016) suggested that L. vulgaris primarily consumed sardine and anchovy. The study showed significantly less overlap in the diet of two squids (L. vulgaris and I. coindetii) than there was between $L$. vulgaris and both Atlantic bonito Sarda sarda and horse mackerel Trachurus mediterraneus. Loligo vulgaris did not show clear seasonal differences in $\delta^{15} \mathrm{~N}$ and $\delta^{13} \mathrm{C}$ values, implying that feeding habits are not changing significantly during the year (or at least that the prey eaten in different seasons have similar trophic levels).

\subsection{Fishery management and conservation}

Three recent studies are of significant interest for fishery management. A study on the recreational cephalopod fishery in Galicia (Palas and Pita, 2015) revealed Loligo vulgaris to be one of the two most exploited cephalopod species (along with $S$. officinalis). Recreational fishery catches account for approximately $30 \%$ of total squid catch in the Ría de Vigo and these data should be included in reported catches to be available for future stock assessment and management. Based on the application of production models (and assuming that the proportion of L. vulgaris in landings is the same as recorded during monthly sampling in Port-en-Bessin), Malhomme et al. (2015) suggested that the current status of the $L$. vulgaris stock is close to the optimum sustainable yield, but that mortality due to recreational fishing in the English Channel could be sufficient to result in overexploitation of the stocks. These results were consistent with previous work by Royer et al. (2002) who fitted Thompson and Bell production models to English Channel fishery data. Model diagnostics suggested that the species was slightly overexploited. Pilar-Fonseca et al. (2014) showed how integration of geo-referenced fisheries data and data on population structure for L. vulgaris in Portuguese waters can allow detailed description of its distribution. It was found that the main fishing season coincides with the period when squid migrate inshore to breed. Thus, higher direct fishing effort on squid at this time could lead to depletion of the stock due to reduction of population reproduction potential.

\subsection{Other studies}

Using morphological and/or molecular methods (the latter approach may be the only option for very small or damaged specimens), it is possible to rapidly, reliably and cost-effectively separate $L$. vulgaris and $L$. forbesii to species level. In adult individuals of $L$. vulgaris, it is apparent that the tentacular club's two rows of inner suckers are much larger than the outer rows, whereas in $L$. forbesii, the suckers are of similar size. Gathering species-specific information in fisheries landings is thus possible but requires an increased effort, for example, regular market sampling, with sub-sampling of large hauls of species admixtures in zones where the species overlap, e.g. in the south Celtic Sea, English Channel and in the North Sea. In recent years, Cefas has invested effort into identifying squid catches to species level on-board their research vessels, resulting in an identification guide by Laptikhovsky and Ouréns (2017). The fact that there are differences in the biology (including life cycle phenology) of $L$. forbesii and $L$. vulgaris (e.g. Oesterwind et al., 2010) illustrates the need for identification to species level for stock assessment and fishery management reasons.

Feyjoo et al. (2016) presented a new scale for the description of embryonic development stages: (1) eyeless eggs, (2) eye rudiments in embryos, (3) funnel tube rudiment present, embryo and yolk clearly separate, (4) fins rudiments present, (5) suckers and gill lamellae present, posterior limit of the head cover, (6) first chromatophores present, (7) mantle elongate and tentacle rudiments clearly longer than arm rudiments, and (8) complete primary lid over eye. As this method of identifying embryonic development stages is non-invasive, it can be applied at sea, by scuba divers, or in the laboratory.

A Croatian study (Zavadlav et al., 2019) evaluated utilizing bioelectrical impedance of $L$. vulgaris during chilled storage to determine how long samples had been stored for, though it was not possible to determine squid freshness.

Vidal and Boletzky (2014) reviewed the culture potential of the species, identifying the barriers to the species becoming a target species for commercial culture as their high live food requirements (which also vary depending on the size of the specimens), their active swimming behaviour, and modest adult size, all of which are likely to limit profitability.

Other studies from recent years refer to biomedical applications of squid. Cozza et al. (2016) evaluated L. vulgaris' collagen fractions from its mantle, concluding that the squid offers a potential alternative collagen-derived materials source. Similarly, Abdelmalek et al. (2016) considered the squid's skin to contain gelatine high in amino acids and of good quality, and Nadarajah et al. (2016) found L. vulgaris to have ink suitable for antimicrobial, antioxidant and anti-inflammatory applications. The growing fascination with squids in the pharmaceutical industry might result in an increased demand for L. vulgaris.

\section{Loligo forbesii}

\subsection{Introduction}

The veined squid (Loligo forbesii) is another representative of the genus Loligo of significant commercial value in European waters. Although it is less heavily exploited than L. vulgaris, its annual landings may reach more than $20000 \mathrm{t}$ (Jereb et al., 2015). In the older literature and some recent papers, the scientific name is given as L. forbesi. Allcock (2010) makes clear that is an error, and we reproduce her argument in full here since it is evidently still not universally recognised: "Virtually all authors for this species, from Joubin (1895) to the present day, have used "forbesi". However, Steenstrup $(1856,1857)^{4}$ clearly states that he is naming the species after Professor Edward Forbes; the Latinization of Forbes is Forbesius, and the genitive of this is forbesii, and Steenstrup consistently ends the species name -ii throughout the manuscript. Although it is permissible for the describer not to Latinize the name (which would produce the spelling forbesi), the spelling is fixed at the time of description, if the describer (i.e. Steenstrup in this case) constructed the name correctly (see Articles 31-32 of the ICZN), which he

\footnotetext{
${ }^{4}$ Steenstrup (1856) is the original reference, in Danish, while Steenstrup (1857) is an English translation of the same work. Here we amended the original text in Allcock (2010) so as to cite both versions.
} 
clearly did.".

The most important knowledge gaps identified by Jereb et al. (2015) were (1) the lack of tools allowing fast and easy separation of $L$. vulgaris and $L$. forbesii; (2) the need for the development of a scientifically supported fishery management strategy for the species, considering artisanal fishery and its impact on the squid stocks; and (3) studies on distribution and migrations. Except for the development of identification tools, these knowledge gaps have remained unfilled. Other studies describe tools to assist in distinguishing $L$. forbesii from other squids in UK waters and how their use can help scientists and citizen-scientists collect data to a higher taxonomic resolution.

\subsection{Environmental effects, distribution and abundance}

A statistical modelling study on post-recruit life stages (Smith et al., 2013) revealed habitat predictors of squid at different maturity stages. It was shown that in winter, squid were associated with lower salinity, while in spring and summer, they were more associated with higher salinity. A higher abundance of squid at shallower depths was seen in summer and autumn and squid aggregations were more associated with gravel substrate than with mud.

\subsection{Life history}

The Thünen-Institut, Germany, and Cefas, England, have attempted to ascertain age information from $L$. forbesii (along with $L$. vulgaris) statoliths but, to date, results have been inconclusive, perhaps primarily due to small sample sizes where different cohorts were mixed (Oesterwind et al., 2019); - see also L. vulgaris section above. Eye lens analysis (Agus et al., 2018) revealed a strong relationship between lens increments and mantle length and weight. If increments are deposited daily, this would suggest that $L$. forbesii males live for up to 18 months and females live for up to 16.5 months. These lifespans exceed estimates based on statoliths but the periodicity of increment formation in eye lenses is unknown.

\subsection{Fishery management and conservation}

The status of the English Channel stock was assessed by Malhomme et al. (2015), showing that this squid in this area is overexploited. The potentially important role of squid in the ecosystem of the English Channel was highlighted, with recommendations provided on methods to evaluate this. Most recently, modelling (accounted for ocean warming) has predicted that UK habitat suitability for $L$. forbesii will have increased by 7\% between 1985 and 2050 (see L. vulgaris section for further detail) (Engelhard et al., 2018). It remains an issue that $L$. vulgaris and $L$. forbesii are not routinely separated in commercial landings statistics, providing plenty of scope for misinterpretation of spatiotemporal population dynamics if data on both species are pooled (intentionally or otherwise).

\subsection{Other studies}

Morphological and genetic tools (for smaller samples) are already available to permit rapid routine separation of $L$. forbesii and $L$. vulgaris in commercial and survey catches. However, more effort is required to provide such data routinely to permit reliable separate assessments of stocks of these species in the zones where they overlap. The recently published ID guide by Laptikhovsky and Ouréns (2017) has allowed for continental shelf cephalopods of UK waters to be more easily identified by scientists on-board fish surveys. Furthermore, a cephalopod identification guide for the North Sea has been created by Drerup and Cooke (2019a), based on previously published material (content is taken mainly from FAO guides and Jereb et al. (2015)) with the intention of the guide being for use by SCUBA divers. This guide might aid the UK's Marine Conservation Society's 'SeaSearch' programme or The
Cephalopod Citizen Science Project, which use volunteer SCUBA divers to record information on habitat, species abundance, depth and water temperature during their dives. Such information, depending on the reliability of the data, can be used to fill gaps in knowledge of distribution and abundance (such as in times/areas not covered by survey vessels).

Vieira et al. (2020) examined the mercury content of Portuguese L. forbesii, finding that specimens did not exceed the permissible levels for human consumption. Further, they found that higher mercury levels in females were related to their larger sizes when compared to males.

\section{Alloteuthis spp}

European common squid Alloteuthis subulata and midsize/little squid A. media have the widest distributions among European myopsid squids. In addition, $A$. media is considered to be a suitable species for laboratory research on cephalopod growth and its responses to changes in environmental conditions, due to its small size, high growth plasticity and easily interpretable statolith microstructure. However, perhaps due to a lack of direct commercial interest in most parts of Europe, although Alloteuthis is targeted by fisheries in Galicia (North West Spain), these species have been much less studied than Loligo spp..

The identification to species level of $A$. subulata and $A$. media remains an issue: the need for (1) reliable species identification was the primary research gap noted by Jereb et al. (2015), along with (2) knowledge of the species' life history, which has been complicated by uncertainty about the reliability of historical identifications of the two species. As stated by Jereb et al. (2015), "real doubts remain as to the true taxonomic affiliation of the animals we currently think of as A. subulata and A media." Although at least two different morphotypes can be identified and are often assumed to characterise the two species, in practice, identification of Alloteuthis to species by traditional morphological methods is nearly impossible. It seems that different morphotypes may occur in both species; one possibility is that a consistent relationship between species and morphotype is only found in areas where both species coexist. The issue of lack of consistent correspondence between genotype and morphotype in Alloteuthis still needs to be resolved and reliable identification methods developed, not least to ensure that stocks can be assessed, and sustainable exploitation assured. The urgency of such work has arguably increased because Alloteuthis abundance in the English Channel and Irish Sea appear to be increasing (McKeown et al., 2015).

While most studies of Alloteuthis spp. continue to refer to the species studied, unless identifications are supported by genetic information, they should be considered as provisional.

Gebhardt and Knebelsberger (2015) found three morphotypes of Alloteuthis in the North and Baltic seas, but the analysis of COI and rDNA did not confirm any genetic differences between them. A study on Alloteuthis paralarvae in the English Channel indicated the possibility of separating the two species using PCR-RFLP (McKeown et al., 2015), although the species identity of the adult reference material cannot be confirmed due to known issues with pairing morphotypes with genotypes and taxonomic species type material in this group.

In other loliginids, identification methods based on analysis of the shape of the body, beak or statolith, and of beak colour, appear to be quite promising (Fang et al., 2016a, b, Green et al., 2015; Jin et al., 2017; Lishchenko et al., 2017), although these methods still need to be tested on Alloteuthis.

Analysis of a 35-year series of squid catch data during trawling surveys in the North Sea showed that Alloteuthis dominated in catches from shallow areas (depths $<50 \mathrm{~m}$ ) of the Southern North Sea during August and September. Alloteuthis was the most common myopsid squid in this area and had expanded its range northwards and increased in abundance over the study period (Barrett and Laptikhovsky, 2017). Quetglas et al. (2014) reported that $A$. media was among the three most numerous cephalopods in the Western Mediterranean, although it was 
observed only in the bottom water layer and showed high seasonal variability in occurrence.

One of the few studies on Alloteuthis ecology is from the North Sea, where age determination of individuals showed that mantle lengths in the range 35 and $141 \mathrm{~mm}$ corresponded to ages between approximately 114 and 370 days (Oesterwind et al., 2019). Studies on trophic relationships of $A$. media have shown that the paralarvae consume prey from ten orders belong to five different phyla; the most frequently detected families being Campanulariidae (order Leptothecata, phylum Cnidaria), Paracalanidae and Clausocalanidae (order Calanoida, phylum Arthropoda) (Olmos-Pérez et al., 2017). In the adults, teleost fishes make up $84 \%$ of the diet, followed by crustaceans ( $8 \%$ ), and molluscs (3\%) (Rosas-Luis and Sanchez, 2015).

\section{Illex coindetii}

\subsection{Introduction}

Within the European ICES areas, landings of ommastrephids fluctuated between around $1000 \mathrm{t}$ and $5500 \mathrm{t}$ annually over the period 2000-2018 (ICES, 2020). These commercial catches mainly consist of Illex coindetii, Ommastrephes caroli, Todarodes sagittatus and Todaropsis eblanae. Illex coindetii is a widespread squid of increasing commercial value; the distribution covers both sides of the Atlantic and the Mediterranean Sea from surface waters to approximately $1000 \mathrm{~m}$ depth.

According to Jereb et al. (2015), further studies were needed on (1) the systematic and ecological status of $I$. coindetii morphotypes, (2) stock structure (both spatial and temporal) and (3) life-history, the latter reflecting the potential role of the species as an indicator or environmental and ecological changes. It should also be noted that (4) environmental drivers of distribution and abundance in this species remain poorly understood. Within the last few years, new information about life history and distribution was published but linkages to environmental drivers are still lacking. Some progress has been achieved in elucidating stock structure in the Mediterranean Sea, but stock structure in the Atlantic is still unknown. Given the lack of recent progress in relation to the majority of priority research topics identified in the previous review (Jereb et al., 2015), priority fields for the future studies remain the same. Further research on the environmental drivers of changes in species distribution, abundance and life history is also needed.

\subsection{Environmental effects, distribution and abundance}

While squids of the family Ommastrephidae occur throughout most of the Northern and Central North Sea, aggregations of I. coindetii were previously mainly observed in low numbers in the central part of the North Sea in winter (in 2008, 2009 and 2010) while its occurrence was very sparse in summer (Oesterwind et al., 2015). However, over the last few years it has expanded into the Northern North Sea, where its biomass continues to increase in winter and summer (Oesterwind et al., 2020). Furthermore, individuals were fished in the Kattegat, Belt Sea and Western Baltic Sea for the first time in 2018, illustrating an expansion further eastward and, notably, the presence of the species in brackish waters with salinities between 20.5 and 33.8 (Oesterwind and Schaber, 2020).

Recently it has been suggested that 4-8 separate stock units exist in the Mediterranean Sea, based on a Constrained Clustering analysis of six biological indicators (biomass, density, mean weight, sex ratio, \% of spawning females, median length of spawning females) (Fiorentino et al., 2014). Based on synchrony of temporal trends in I. coindetii across the Mediterranean, Keller et al. (2017b) suggest that there are only 1-2 populations. Lauria et al. (2016) reported the highest abundances of I. coindetii at depths of less than $200 \mathrm{~m}$ and more than $600 \mathrm{~m}$, and a minimum abundance at $\sim 400 \mathrm{~m}$. The greatest concentrations of squid are observed in the most highly productive zones, related to the Atlantic Ionian Stream (Lauria et al., 2016). In the North West Mediterranean
(East Iberian coast), local abundance was negatively correlated with depth, probably because of recruitment at shallow depths (Puerta et al., 2014b), illustrating the fact that the responses of I. coindetii to environmental drivers are complex, due to the high mobility of individuals and the constant mixing of subpopulations in neighbouring areas.

\subsection{Life history}

As recorded elsewhere in its range, in the East Mediterranean (Adriatic and Aegean Seas), I. coindetii is an intermittent terminal spawner (Ceriola and Milone, 2017; Salman, 2017). Alongside the apparent expansion of the species into the Northern North Sea and Baltic Sea (Oesterwind et al., 2020; Oesterwind and Schaber, 2020), there is now evidence of a summer spawning stock of Illex coindetii in the North Sea. Oesterwind et al. (2020) observed up to three bundles of spermatangia attached to females in quarter 3 , suggesting that spawning and reproduction takes place in the North Sea. They further suggest that the egg masses described in the North Sea area and adjacent waters (Ringvold and Taite, 2018) belong to Illex coindetii. This suggestion has been recently supported by the findings of Ringvold and her team, who genetically analysed four spheres from Norwegian waters and identified them as egg masses of Illex coindetii ${ }^{5}$. Estimated hatching dates suggest a prolonged hatching season, at least from June to December, and therefore a long spawning season, although cold temperature seems to preclude year-round reproduction in the North Sea and adjacent waters (Oesterwind et al., 2020). Age-readings revealed a $\sim 1$-year life cycle in the North Sea (Oesterwind et al., 2020), as also described for waters south to the area of the study (e.g. González et al., 1996).

On evolutionary timescales, while early ommastrephids spawned in coastal waters, a gradual evolution of the spawning type has occurred since the Cretaceous, with some species subsequently switching to spawning in oceanic waters (Pardo-Gandarillas et al., 2018). Because coastal oceans are expected to undergo important climate-induced changes and to be subject to increasing anthropogenic pressures (Reusch et al., 2018), it might be expected that life-cycle changes in coastal-spawning species will be more pronounced than in oceanic-spawning species.

\subsection{Ecology}

The diet of $I$. coindetii in the Mediterranean is highly diverse and individuals may take as many as 35 different prey species, mainly crustaceans, squid and mesopelagic fish. Diet composition depends on ontogenetic stage: the diet of juveniles mainly consists of crustaceans, especially in winter, while adults prey mainly on fish and crustaceans, apparently with no seasonal differences. It is not clear to what extent these differences reflect the development of the beak and/or on the availability of the prey in the areas where the squid live (Martínez-Baena et al., 2016).

In the Strait of Gibraltar, results from stomach contents analysis indicate that $I$. coindetii is one of the main prey of swordfish (Xiphias gladius) (Abid et al., 2018), while stable isotope analysis results suggest that ommastrephid squid (I. coindetii and/or T. eblanae) are important prey for Atlantic bluefin tuna (Thunnus thynnus) (Varela et al., 2018). It is also a common prey for small-spotted catshark (Scyliorhinus canicula) (Kousteni et al., 2018). Changes in distribution and abundance of I. coindetii will presumably also result in changes in trophic relationships, in its role as both predator and prey.

\footnotetext{
5 Sea Snack Norway. "Mystery on large gelatinous spheres solved!" Sea Snack Norway Press Release, 17 Sep. 2019. https://buzzingkid.no/Images/en gpressegelb2019.pdf
} 


\subsection{Fishery management and conservation}

In deep waters of the Egyptian Mediterranean Sea, growth parameters, mortality, and size at maturity were estimated for the first time. Estimated exploitation rates suggested that the stock was overexploited, and that overexploitation was higher in females than males (Amin and Sabrah, 2019).

\section{Ommastrephes bartramii / O. caroli}

\subsection{Introduction}

The genus Ommastrephes represents a complex of species with circumglobal distribution, with high commercial importance outside the ICES areas. In North Atlantic waters, the species until recently considered to be Ommastrephes bartramii is less common and its commercial value markedly lower; its importance among ommastrephid squid catches in Europe is unknown but is likely to be low. Here we follow Fernández-Álvarez et al. (2020) in designating specimens from the North Atlantic and Mediterranean as $O$. caroli. The comprehensive review of molecular, morphological and physiological traits by these authors showed that the species inhabiting the North Atlantic waters differs from that in North Pacific waters.

Aside from the recently addressed issue (1) of the systematics, Jereb et al. (2015) noted that (2) general information on the basic biology of $O$. caroli in the North Atlantic was still needed and that (3) translation of the published Russian studies into English would help make the available knowledge more accessible. There have been few recent studies of $O$. caroli from the North Atlantic and Mediterranean and, having reviewed several studies on $O$. bartramii from Pacific waters prior to the publication of Fernández-Álvarez et al. (2020), we also briefly report on them here. The recent studies provide new information on distribution and life history. For future research, studies on the life history, distribution and environmental impacts are of the greatest interest along with the translation of Soviet and Russian studies.

\subsection{Environmental effects, distribution and abundance}

New information is available about the distribution of this species (which we now assume to be $O$. caroli) in the Mediterranean Sea (Lefkaditou et al., 2013; Franjevic et al., 2015). The frequency of observations of young specimens has increased significantly since the beginning of 1990's (Lefkaditou et al., 2013), which probably reflects spawning in this, or adjacent, area(s). Recent records of large females in this area support this hypothesis. In combination with new captures of mature females in the Adriatic Sea (Franjevic et al., 2015), the new information suggests that the range is expanding, possibly linked to climate change. In general, global warming seems to have a positive effect on abundance of this species and to favour its expansion into high-latitude waters. There have been numerous studies of the effect of abiotic factors on the distribution and abundance of this species in the North West Pacific (e.g. Alabia et al., 2015; Feng et al., 2016, 2017; Lin et al., 2019a; Xu et al., 2016; Wang et al., 2017; Yu et al., 2015, 2016).

\subsection{Life history}

In the Pacific, the age structure of $O$. bartramii has been described on the basis of counts of growth increments in various hard structures, which could also be applied in Atlantic Waters (Fang et al., 2016a; Liu et al., 2015). Other recent studies concern identification of beaks and statoliths recovered from predator stomachs, stock identification and migration patterns (Fang et al., 2014a, b; Fang et al., 2017; Fang and Chen, 2018; Fang et al., 2016c; Hu et al., 2018; Kato et al., 2016). Fastand slow-migrating individuals might be distinguished by differences in the statolith. Statolith shape is apparently not useful to differentiate between closely related ommastrephid squid species but may be more useful for more distantly related species. Some intra-specific variation in statolith shape in $O$. caroli appears to be associated with ontogenic changes (Fang and Chen, 2018) and, therefore, might be useful to distinguish individuals from different seasonal cohorts.

\section{Todaropsis eblanae and Todarodes sagittatus}

\subsection{Introduction}

Todaropsis eblanae occurs in shelf waters throughout the North East Atlantic and Mediterranean. Todarodes sagittatus is a migratory species, widely distributed in the North East Atlantic and Mediterranean, and occurring in both neritic and oceanic waters. Both species are taken by fisheries, with Todaropsis regularly landed together with Illex coindetii. Todarodes shows more sporadic occurrence but in the early 1980s it was the basis of a substantial squid fishery in Norway. Landings of ommastrephid squids are often pooled and recorded simply as "Ommastrephidae" or short-finned squid.

Jereb et al. (2015) noted (1) the need to identify the landings of ommastrephid species adequately in the North East Atlantic, as well as (2) the need for more research on stock separation, distribution and (3) life history including detection of spawning sites, and studies on egg development and early life stages. Additional research priorities identified included (4) validation of the periodicity of statolith increment deposition in T. sagittatus, and (5) studies on parasite communities of T. eblanae as a means to understand migrations as well as to determine the impact of parasites on the squid growth.

There has been little reported progress on the research topics mentioned above. However, new information about distribution and feeding ecology, as well as a new tool to identify paralarvae of ommastrephids, are available. Several studies addressed distribution and abundance of T. sagittatus and T. eblanae. Nevertheless, further studies on distribution and abundance, as well as life history and ecology of these species are needed.

\subsection{Environmental effects, distribution and abundance}

A study on squid distribution and abundance in the North Sea (Oesterwind et al., 2015) showed that Todaropsis eblanae was the most widespread ommastrephid species in this area while Todarodes sagittatus was found to be the least common, possibly because it passes through the area only when migrating between feeding areas and the spawning areas on the mid-Atlantic ridge and western continental slope of Europe. Recent surveys performed by Cefas (C. Barrett, pers. comm.) found that T. eblanae was abundant only in the western part of the North Sea. More recent results from the area show a strong increase of $I$. coindetii, so that T. eblanae is currently only the second most important ommastrephid in the area based on data of the International Bottom Trawl in Quarter 1 and 3 (Oesterwind et al., 2020). Previous studies suggest that high abundance of both species in the North East Atlantic may be sporadic and that large shifts in distribution can also be seen.

In the Central Mediterranean Sea, Lauria et al. (2016) found that the spatial distribution of T. eblanae was related to the temperature regime, salinity and chlorophyll-a concentration, suggesting a preference for highly productive areas associated with the Adventure Bank Vortex.

\subsection{Ecology}

A study on feeding habits of Todarodes sagittatus in the North West Mediterranean (Rosas-Luis et al., 2014) illustrates that the species has a wide prey spectrum: 49 types of prey were identified, most being mesopelagic fish, decapod crustaceans and amphipods. It was concluded that $T$. sagittatus feeds opportunistically on the most accessible prey, adjusting its vertical distribution in the water column according to the availability of prey resources. The diet composition also depended on the size of squid: small squid primarily consumed small crustaceans, 
squid of medium size fed upon medium-sized fish, and large individuals fed on larger fish, crustaceans and molluscs.

As noted in section 11 above, ommastrephid squid are apparently important as prey for bluefin tuna in the Gibraltar area (Varela et al., 2018). However, the authors were not able to distinguish between Illex and Todaropsis.

\subsection{Other studies}

A new identification key for paralarvae of ommastrephids (I. coindetii, T. eblanae, T. sagittatus) based on morphological differences (Fernández-Álvarez et al., 2017) provides a cost-effective and reliable tool for studies on the life-cycles and population dynamics of ommastrephid squids in the North Atlantic. Among the most useful characters were the relative size and the arrangement of pegs on the lateral and medial proboscis suckers and the presence of photophores.

Citizen science may be a useful tool to identify spawning sites of ommastrephids, as indicated by reports of probable oegopsid eggs (floating gelatinous spheres) by divers in Northern Europe and the Mediterranean (Ringvold and Taite, 2018). These authors tentatively identified some of the eggs as belonging to Todarodes sagittatus (see section 11.3).

\section{Gonatus fabricii}

\subsection{Introduction}

Gonatus fabricii is a boreoatlantic oceanic oegopsid squid. It is the most abundant squid of the Arctic and Subarctic waters of the North Atlantic and might have some fishery potential. The species has been assessed by the International Union for Conservation of Nature (IUCN) as of Least Concern (Barratt and Allcock, 2014). In the North Atlantic, its distribution overlaps with that of Gonatus streenstrupi, creating the potential for misidentification (Jereb et al., 2015).

In the most recent review on the European cephalopod life history, Jereb et al. (2015) highlighted the need for improved knowledge of its (1) distribution, aggregation patterns and migration and (2) its role in the food web. Molecular genetic studies were indicated as a promising source of information on the latter topic. Advances have been seen for both topics and additional information on life history of the species has been published.

A new comprehensive review of our knowledge of this species is of an interest along with collection of information about its migrations.

\subsection{Environmental effects, distribution and abundance}

In addition to the comprehensive information about the species' distribution in Jereb et al. (2015), some additional information on the biomass and abundance of $G$. fabricii in the Barents Sea and adjacent waters has been published recently (Golikov, 2014; Golikov et al., 2017). Golikov et al. (2017) reported a maximum biomass of $G$. fabricii of approx. 25,000 t and an abundance of 1.7 billion specimens with higher concentrations in deep water troughs in the marginal parts of the Barents Sea and adjacent deep-water areas. They further propose that the importance of cephalopods in the Arctic ecosystem is lower compared to the Antarctic and Tropics due to the lower biomass. Xavier et al. (2018) found that variation in abundance and biomass of G. fabricii in the Arctic was unrelated to climatic conditions in 2009-2012. Shea et al. (2017) described the presence of G. fabricii at Bear Seamount, which is the most inshore seamount in the New England seamount chain.

\subsection{Life history}

Although Golikov et al. (2019) present evidence for two new breeding areas, namely SouthEast Greenland and the north western part of the Davis Strait, their study supports the assumption that G. fabricii reproduces only in a few geographically restricted areas, which might be due to the patchy distribution of food availability in the Arctic. They further studied the reproduction of $G$. fabricii in detail, reporting synchronous oogenesis, and found that mean fecundity decreased during maturity stages II to V (although only one IV and two stage V females were sampled). The spermatophores do not have a tapered, sharp tip to the cement body and are different to those of Berryteuthis magister, another member of the Gonatidae. Furthermore, spermatophores produced later in life show an increase in length and width and in the volume of the seminal reservoir, compared to those produced earlier, while the size of mature males does not impact the number of spermatophores. There was no evidence of differences in sizes at maturity between the different geographical areas.

\subsection{Ecology}

Stable isotope analysis was used to investigate the trophic position of G. fabricii in Arctic waters and results indicate that adults are upper level predators with an estimated maximum trophic level up to 5.1 in the ecosystem (Golikov et al., 2018) (although it should be noted that they are generally not "top" predators given their importance as prey of various marine mammals (e.g. Bjorke, 2001)). Both $\delta{ }^{13} \mathrm{C}$ and $\delta{ }^{15} \mathrm{~N}$ values of $G$. fabricii were independent of sex and site, but depend on the squid size: $\delta{ }^{13} \mathrm{C}$ values show a small increase and $\delta{ }^{15} \mathrm{~N}$ values show a substantial ontogenetic increase from epipelagic juveniles to large bathypelagic adults. In agreement with previous studies (Cherel et al., 2008) the authors conclude that polar squids have a higher trophic level than squids in warmer regions.

\section{Summary}

Studies on cephalopods in European waters published during 2013-2019 were largely focused on three species, Octopus vulgaris, Sepia officinalis and Loligo vulgaris, the first of which was the subject of over 100 journal articles. While some progress was made on better understanding of environmental effects on $O$. vulgaris populations, further research is still required on early life stages (including their distribution and abundance) and work is needed to develop better artificial diets for paralarvae. Recent work on the species status of $O$. vulgaris (Amor et al., 2017) has revealed that it is a cryptic species complex and hence there is a need for further research into possible cryptic species within Europe.

Eledone cirrhosa and E. moschata, by contrast, were the subject of less research activity and most priority areas outlined by Jereb et al. (2015) still require attention, namely, identification of spawning sites and knowledge about early life stages in $E$. cirrhosa, reproductive biology in general of $E$. moschata and stock identification for both species. Studies on stock status are needed in this group, which is of increasing commercial interest. Some progress was made in age determination for E. cirrhosa using stylets (Regueira et al., 2015) and beaks (Ikica et al., 2014).

Significant advances were made over the review period in Sepia officinalis, including in the priority areas (as identified by Jereb et al. (2015)) of climate change effects on populations and elemental/isotopic profiles of hard structures, but stock identification remains a gap for this species. Isotopic analysis of hard parts indicated the water masses in which the animals lives (e.g., inshore versus offshore) (Dance et al., 2014). Some advances have been made in age determination using beaks but methods are not yet fully validated (Lishchenko et al., 2018a). Continued monitoring of stock status is important for this species in certain areas, such as the English Channel where $S$. officinalis is exploited at different times of year by English and French fishers using both traps and trawls, and where very high and very low abundances have both been the subject of newspaper articles in the last few years. Therefore, environmental drivers of abundance, including impacts of climate change continue to be relevant. High rates of IUU fishing are cause for 
concern in some areas (Gulf of Sicily; Falautano et al., 2018), along with losses of $S$. officinalis to recreational fishing (Ría de Vigo) and egg mass loss on traps (Bloor et al., 2013), with solutions also being proposed to address these losses (Melli et al., 2014; Davies and Nelson, 2018). Given the reliance of this species on inshore habitats within the fished parts of their range, sensitivity to pollution is another priority area for research in this group. A two-stage stock assessment model may improve assessment of winter biomass that falls outside the seasonal exploitation period (Gras et al., 2014).

Over the review period, little work on $S$. elegans and S. orbignyana was published, and recent studies concerned distribution (mostly in adults) and basic reproductive biology. Priorities for work on these species are thus mostly unchanged from Jereb et al. (2015), including a need to better understand the systematic position of these species and better species-level reporting in fisheries landings. More knowledge is also required on their life history including early life-cycle stages.

Two priority research areas had been identified for Sepietta oweniana: separation of stocks and cohorts and better identification tools (Jereb et al., 2015). Progress has been made in relation to the latter but none on the former. Several studies added to knowledge of the habitat of this species and on its value as prey to many elasmobranch predators. Because this widespread species is likely to be an important prey item for many predator groups, monitoring of its stock status is recommended.

Three priority areas were identified by Jereb et al. (2015) for Loligo vulgaris: impacts of global warming, trophic relationships and identification tools for field sampling. A substantial number of research articles, representing some progress in all three areas was published over the period covered by this review. All but the smallest individuals of L. vulgaris can be identified to species level using existing tools; we recommend the use of these tools, particularly during research surveys and for monitoring of landings. The likely effects of global warming and ocean acidification were partially addressed and shifts in distribution and breeding phenology warrant monitoring, e.g. in the North Sea. More is now known about the diet of $L$. vulgaris, which overlaps with that of several fish species, and its contribution to the diet of various predators. Given the very high commercial interest in this species, a better understanding of migration routes and seasonality would be valuable, especially as these may be affected by global warming. Research into fishing intensity on L. vulgaris highlights the importance of recreational fishing and suggests that catches are sufficiently high to warrant seasonal fishing closures in some areas.

In $L$. forbesii, species identification tools suitable for use in commercial fisheries were also highlighted as a priority by Jereb et al. (2015), along with scientific support tools for fisheries management and knowledge of migrations. Various identification tools are available which now need to be put into practice in surveys and (ideally) data collection from landings. In fact, little research has been published in the intervening years on this species. Some progress has been made in understanding distribution throughout the seasonal cycle (Smith et al., 2013). Age determination using the eye lens has been investigated in both $L$. vulgaris and L. forbesii and there are apparently more increments than are seen in the statoliths. However, the periodicity of increment deposition in the eye lens remains unknown. Aspects of biology differ between these species (Oesterwind et al., 2010), which makes them an interesting study system, given their overlapping ranges and potentially different and competing reactions to global warming (van der Kooij et al., 2016; Engelhard et al., 2018). Their geographical overlap and high commercial importance, especially in areas like the English Channel, mean that better identification of landings would support improved fisheries assessments in both $L$. forbesii and $L$. vulgaris.

Alloteuthis spp. is a group for which good species identification tools are still needed throughout their European range, despite several recent studies (e.g. Gebhardt and Knebelsberger, 2015; McKeown et al., 2015). Morphometric plasticity within these species frustrates species identification but also demonstrates that this might be an interesting avenue of future research. Because of this key issue, Jereb et al. (2015) noted that existing information on life history generally referred to specific morphotypes in specific areas, and doubts exist about which genetic species was being studied. In common with several species covered in this review, Alloteuthis spp. appear to have expanded their range in the last 35 years (Barrett and Laptikhovsky, 2017). Despite identification issues, some progress has been made in better understanding the distribution of this genus.

Commercial interest in Illex coindetii is increasing; Jereb et al. (2015) suggested the need for a better understanding of stock status, stock separation and life history. Some work on stock separation has taken place in the Mediterranean (Fiorentino et al., 2014; Keller et al., 2017b) but more is required, particularly since there is evidence of recent range expansion (Oesterwind et al., 2015, 2020; Oesterwind and Schaber, 2020). More information on life history is now available, pointing towards a long spawning season and flexible maturity in I. coindetii.

Some advances have been made on understanding of the distribution and biology of Ommastrephes (presumably $O$. caroli) in the Mediterranean. Like many of the species in this review, range expansion of Ommastrephes spp. has been proposed for several areas in both Mediterranean and Pacific, associated with warmer oceans (Lefkaditou et al., 2013; Alabia et al., 2015). Work on interpreting statolith shape and increments has been restricted to $O$. bartramii in the Pacific.

Given their commercial importance and extensive migrations, the fact that landings are usually identified only to family level was highlighted as an area of concern for Todaropsis eblanae and Todarodes sagittatus by Jereb et al. (2015), along with stock separation, identification of spawning sites, migration (in T. eblanae), and age determination and growth (in T. sagittatus). Gaps in our knowledge of early life history were also highlighted in the past but this issue has been addressed with the provision of morphological identification criteria which are now available for early life stages (Fernández-Álvarez et al., 2017). Knowledge gaps remain in the other topic areas.

Finally, as an abundant squid of the Arctic region, it was suggested that the position of Gonatus fabricii in the foodweb was a priority research area (Jereb et al., 2015). There have been some recent advances on this topic (e.g. Golikov et al., 2018) but there is a continued requirement for a better understanding of its distribution and migration patterns. Previous studies of predator diets have distinguished between G. fabricii and its southern congener G. steenstrupii based on the known distributions of the two species and there is a need for tools to distinguish these two species in predator diets (e.g. from their beaks), especially in areas where their ranges overlap (see Jereb et al., 2015).

\section{Concluding remarks}

There is an ongoing need for systematic collection of species-level data (amounts caught, biological information) from fisheries including recreational and illegal fishing and fisheries discards - and from fishery-independent surveys, to support stock assessment, the provision of management advice, and the monitoring of the success of management interventions. Obtaining useful data at a sufficiently high temporal resolution also remains a challenge. While similar statements have been made frequently about European cephalopod stocks over the last 30 years, regulation of fishery catches of cephalopods (in both largescale and small-scale fisheries) are still not addressed under the EU Common Fisheries Policy and, as such, most stock assessments that have been done are academic exercises, generally retrospective. They allow us to determine the exploitation status of the stocks but no mechanism is available to modify fishing practices in response to evidence of overexploitation. Recently, concern has been expressed that, in areas like the English Channel, this lack of oversight may be impacting negatively on cuttlefish and squid stocks and also on small-scale cuttlefish fisheries. Under an Ecosystem Approach to Fisheries Management, as envisaged by the 2013 revision of the Common Fisheries Policy, there is really no excuse for failure to assess all fished cephalopod stocks and manage large-scale commercial fishing on cephalopods. 
While advances continue to be made in cephalopod culture, potentially leading to commercial aquaculture of cuttlefish and octopus, this has also given rise to debates about whether culturing intelligent molluscs is ethical, and similar arguments could be applied to fishing or culture of many marine animals. What is clear, is that ethical considerations are a key aspect not only of human exploitation of cephalopods but also of future research on cephalopods (see O'Brien et al., 2018).

Given its profound implications for every aspect of the life-cycle, and the fact that most of the commercially important species inhabit the rapidly warming coastal oceans (Reusch et al., 2018), research into climate change impacts is required for all species. For example, more detailed distribution data including depth preferences are necessary to understand potential for depth preference shifts due to global warming, as seen in finfish (Dulvy et al., 2008), which could have important ecosystem-level consequences, not least on trophic interactions. Ongoing monitoring, including monitoring of reproductive status at species level in I. coindetii, L. vulgaris and L. forbesii, is highly desirable in the ICES areas where these species overlap, since possible competitive interactions under shifting distributions are beginning to be seen.

A large number of studies report on empirical statistical modelling of environmental preferences, habitat suitability and environmental effects on abundance. While such studies may of course provide insights, for example into possible effects of climate change on cephalopods, caution is recommended in interpretation of models based on data from a limited geographic area and/or short time-series, especially when the mechanisms underlying such apparent preferences are not well understood and when fitted models have not been validated against independent data sets (see Solow (2002) for some cautionary examples based on finfish data).

The systematics and identification of $O$. vulgaris (a species complex), S. elegans and $S$. orbignyana (the systematic position of which remains unclear), and Alloteuthis spp. (which shows intra- and inter-species morphological plasticity), also require more research. Ommastrephes in the Atlantic and Mediterranean is now recognised as a separate species (O. caroli), distinct from the Pacific $O$. bartramii. Better species identification tools are necessary in these groups including tools suitable for use by fishers, fishery inspectors, buyers, and scientists undertaking sampling. New identification guides exist for various life stages in several other groups (e.g. Fernández-Álvarez et al., 2017; Laptikhovsky and Ouréns, 2017, Drerup and Cooke 2019 a, b, c), which now need to be used to collect more reliable and useable information on stock status.

The application of genetic tools is also useful in studies on cephalopods as predators and prey, in the latter case as recently demonstrated in studies on diet of paralarvae (e.g. Olmos-Pérez et al., 2017). Distinguishing the remains of closely related cephalopod species based on visual examination of the beaks found in predator stomach contents can be difficult (e.g. Loligo vulgaris versus $L$. forbesii, Illex coindetii versus Todaropsis eblanae, G. fabricii versus G. steenstrupi). Shape analysis of the beaks (as has been applied in loliginids) offers a possible solution which requires further research.

Citizen science projects may help circumvent some of the constraints of under-resourced monitoring of commercial cephalopod catches and of out-of-season data collection on research cruises (Drerup and Cooke, 2019 a, 2019b, 2019c).

Some progress has been made in age determination for cephalopods using hard structures, but these do not work equally well across different cephalopod groups. For example, while statoliths are commonly used in squid, they are unsuitable for octopus species and some cuttlefish species, where increments are not distinguishable in older individuals (Arkhipkin et al., 2018). On the other hand, daily growth increments in O. vulgaris beaks have now been validated (Perales-Raya et al., 2014a, 2014b; Armelloni et al., 2020) and implemented in several studies on paralarvae (Franco-Santos et al., 2016; Perales-Raya et al., 2018). Further research efforts are required on stock identification methods in all species, not least because, in the absence of formal management of large-scale fisheries, current stock definitions, such as they exist, relate more to administrative convenience than scientific data. Supplementary approaches (e.g. to identify "ecological stocks") should be used to provide a fall-back position if suitable genetic markers are not identified. In fact, pronounced genetic structure may be absent in many cephalopods (Boyle et al., 1996). Ecological stock definition might make use of stable isotope or element composition of recording structures - currently a promising approach - or information derived from electronic or biological tags (parasite fauna are an example of the latter). Microchemistry of cuttlefish bone can indicate migration from spawning to nursery grounds (Dance et al., 2014). The potential of electronic tags in the study of migrations should be noted, since these could provide essential information on environmental conditions experienced during the tag-bearing period (Wearmouth et al., 2013). Finally, gaps remain in our understanding of the mechanisms which underpin cephalopod responses to man-made pollutants, including noise (e.g. Merchant et al., 2016), in the environment.

\section{CRediT authorship contribution statement}

F. Lishchenko: Conceptualization, Investigation, Methodology, Project administration, Supervision, Writing - original draft, Writing review \& editing. C. Perales-Raya: Investigation, Writing - original draft, Writing - review \& editing. C. Barrett: Investigation, Writing original draft, Writing - review \& editing. D. Oesterwind: Investigation, Writing - original draft, Writing - review \& editing. A.M. Power: Investigation, Writing - original draft, Writing - review \& editing. A. Larivain: Investigation, Writing - original draft, Writing - review \& editing. V. Laptikhovsky: Writing - original draft. A. Karatza: Investigation. N. Badouvas: Investigation. A. Lishchenko: Investigation, Writing - original draft. G.J. Pierce: Conceptualization, Investigation, Methodology, Supervision, Writing - original draft, Writing - review \& editing.

\section{Declaration of Competing Interest}

The authors declare that they have no known competing financial interests or personal relationships that could have appeared to influence the work reported in this paper.

\section{Acknowledgements}

This review was conducted under the auspices of ICES WGCEPH. GJP, AMP, CPR and AL were supported by the Cephs \& Chefs project of the European Regional Development Fund through the Interreg Atlantic Area Programme grant number EAPA_282/2016 of the We thank Angel Guerra for his input to discussion about Sepia officinalis off the African coast.

\section{References}

Lishchenko, F., Bartolomé, A., Sykes, A., Perales-Raya, C., 2018a. A novel approach to age estimation of sepia officinalis (linnaeus 1758) - analysis of beak microstructure. Book of Abstracts of Cephalopod International Advisory Council Conference 2018 Cephalopod Research Across Scales: From Molecules to Ecosystems. Cephalopod International Advisory Council, St. Petersburg, p. 115.

Abdelmalek, B.E., Gómez-Estaca, J., Sila, A., Martinez-Alvarez, O., Gómez-Guillén, C., Chaabouni-Ellouz, S., Ayadi, M.A., Bougatef, A., 2016. Characteristics and functional properties of gelatin extracted from squid (Loligo vulgaris) skin. LWT- Food Sci Technol. 65, 924-931.

Abecasis, D., Afonso, P., O’Dor, R.K., Erzini, K., 2013. Small MPAs do not protect cuttlefish (Sepia officinalis). Fish. Res. 147, 196-201. https://doi.org/10.1016/j. fishres.2013.05.004.

Abid, N., Laglaoui, A., Arakrak, A., Bakkali, M., 2018. The role of fish in the diet of swordfish (Xiphias gladius) in the Strait of Gibraltar. J. Mar. Biol. Assoc. U.K. 98, 895-907. https://doi.org/10.1017/S002531541700011X.

Abidli, S., Lahbib, Y., El, Trigui, Menif, N., 2019. Microplastics in commercial molluscs from the lagoon of Bizerte (Northern Tunisia). Mar. Pollut. Bull. 142, 243-252. https://doi.org/10.1016/j.marpolbul.2019.03.048.

Agus, B., Mereu, M., Cannas, R., Cau, A., Coluccia, E., Follesa, M.C., Cuccu, D., 2018. Age determination of Loligo vulgaris and Loligo forbesii using eye lens analysis. Zoomorphology 137, 63-70. https://doi.org/10.1007/s00435-017-0381-8. 
Ajana, R., Techetach, M., Saoud, Y., 2018. Diet of Octopus vulgaris from the moroccan Mediterranean Coast. Thalassas 34, 415-420. https://doi.org/10.1007/s41208-018 0084-z.

Alabia, I.D., Saitoh, S.-I., Mugo, R., Igarashi, H., Ishikawa, Y., Usui, N., Kamachi, M., Awaji, T., Seito, M., 2015. Seasonal potential fishing ground prediction of neon flying squid (Ommastrephes bartramii) in the western and central North Pacific. Fish. Oceanogr. 24, 190-203. https://doi.org/10.1111/fog.12102.

Albo-Puigserver, M., Navarro, J., Coll, M., Layman, C.A., Palomera, I., 2016. Trophic structure of pelagic species in the northwestern Mediterranean Sea. J. Sea Res. 117, 27-35. https://doi.org/10.1016/j.seares.2016.09.003.

Alemany, J., Foucher, E., Vigneau, J., Robin, J.-P., 2015. Stock assessment models for short-lived species in data-limited situations: case study of the English channel stock of cuttlefish (sepia officinalis). In: Anchorage, AlaskaTools and Strategies for Assessment and Management of Data-Limited Fish Stocks - 30th Lowell Wakefield Fisheries Symposium. May 12-15, 2015. https://archimer.ifremer.fr/doc/003 $77 / 48773 /$.

Alemany, J., Rivot, E., Foucher, E., Vigneau, J., Robin, J.-P., 2017. A Bayesian two-stage biomass model for stock assessment of data-limited species: an application to cuttlefish (Sepia officinalis) in the English Channel. Fish. Res. 191, 131-143. https:// doi.org/10.1016/j.fishres.2017.03.010.

Aliaga Taberner, C., 2019. Composición Nutritiva Del Pulpo (Octopus Vulgaris) Alimentado Con Piensos Formulados Con Fuentes Proteicas Vegetales Y Animales. Masters Thesis, 39 pp. University of Valencia, Spain. http://hdl.handle.net/102 $51 / 120065$.

Allcock, L., 2010. Taxonomy. In: Pierce, G.J., Allcock, L., Bruno, I., Bustamante, P., González, A.F., Guerra, A., Jereb, P., Lefkaditou, E., Malham, S., Moreno, A. Pereira, J., Piatkowski, U., Rasero, M., Sánchez, P., Santos, M.B., Santurtún, M., Seixas, S., Sobrino, I., Villanueva, R. (Eds.), Cephalopod Biology and Fisheries in Europe. Co-Operative Research Report 303, International Council for the Exploration of the Sea, 175 pp. (pp. 6-079) ISBN 978-87-7482-078-079.

Alonso-Fernández, A., Otero, J., Bañón, R., Campelos, J.M., Santos, J., Mucientes, G., 2017. Sex ratio variation in an exploited population of common octopus: ontogenic shifts and spatio-temporal dynamics. Hydrobiologia 794, 1-16. https://doi.org/ 10.1007/s10750-016-3065-3.

Altman, J., 1967. The behaviour of octopus vulgaris lam. In its natural habitat: a pilot study. In: Lythgoe, J.N., Woods, J.D. (Eds.), Underwater Association Report, 196667. Industrial and Research Promotions, Carshalton, pp. 77-83.

Amado, E.M., Souza-Bastos, L.R., Vidal, E.A.G., Leite, T.S., Freire, C.A., 2015. Different abilities to regulate tissue hydration upon osmotic challenge in vitro, in the cephalopods Octopus vulgaris and O. Insularis. Mar. Freshw. Behav. Physiol. 48, 205-211. https://doi.org/10.1080/10236244.2015.1024078.

Amin, A.M., Sabrah, M.M., 2019. Basic Parameters for Assessment and Management of the Short-Finned Squid Illex coindetii (Verany, 1839) (Cephalopoda,

Ommastrephidae) from the deep water off the Egyptian Mediterranean Sea. Egypt. J. Aquat. Biol. Fish 23, 13-26. https://doi.org/10.21608/ejabf.2019.25929.

Amor, M.D., Norman, M.D., Roura, A., Leite, T.S., Gleadall, I.G., Reid, A., PeralesRaya, C., Lu, C.-C., Silvey, C.J., Vidal, E.A.G., Hochberg, F.G., Zheng, X., Strugnell, J. M., 2017. Morphological assessment of the Octopus vulgaris species complex evaluated in light of molecular-based phylogenetic inferences. Zool. Scr. 46, 275-288. https://doi.org/10.1111/zsc.12207.

Arechavala-Lopez, P., Minguito-Frutos, M., Follana-Berná, G., Palmer, M., 2019. Common octopus settled in human-altered Mediterranean coastal waters: from individual home range to population dynamics. ICES J. Mar. Sci. 76, 585-597. https://doi.org/10.1093/icesjms/fsy014.

Arkhipkin, A.I., Rodhouse, P.G.K., Pierce, G.J., Sauer, W., Sakai, M., Allcock, L., Arguelles, J., Bower, J.R., Castillo, G., Ceriola, L., Chen, C.-S., Chen, X., DiazSantana, M., Downey, N., González, A.F., Granados Amores, J., Green, C.P., Guerra, A., Hendrickson, L.C., Ibáñez, C., Ito, K., Jereb, P., Kato, Y., Katugin, O.N. Kawano, M., Kidokoro, H., Kulik, V.V., Laptikhovsky, V.V., Lipinski, M.R., Liu, B., Mariátegui, L., Marin, W., Medina, A., Miki, K., Miyahara, K., Moltschaniwskyj, N., Moustahfid, H., Nabhitabhata, J., Nanjo, N., Nigmatullin, C.M., Ohtani, T., Pecl, G., Perez, J.A.A., Piatkowski, U., Saikliang, P., Salinas-Zavala, C.A., Steer, M., Tian, Y., Ueta, Y., Vijai, D., Wakabayashi, T., Yamaguchi, T., Yamashiro, C., Yamashita, N., Zeidberg, L.D., 2015. World squid fisheries. Rev. Fish. Sci. Aquac. 23, 92-252. https://doi.org/10.1080/23308249.2015.1026226.

Arkhipkin, A.I., Bizikov, V.A., Doubleday, Z.A., Laptikhovsky, V.V., Lishchenko, F.V., Perales-Raya, C., Hollyman, P.R., 2018. Techniques for estimating the age and growth of molluscs: cephalopoda. J. Shellfish Res. 37, 783-792. https://doi.org/ 10.2983/035.037.0409.

Armelloni, E.N., Lago-Rouco, M.J., Bartolomé, A., Felipe, B.C., Almansa, E., PeralesRaya, C., 2020. Exploring the embryonic development of upper beak in Octopus vulgaris Cuvier, 1797: new findings and implications for age estimation. Fish. Res. 221, 105375 https://doi.org/10.1016/j.fishres.2019.105375.

Lishchenko, F., Perales-Raya, C., Silva, L., Bartolomé, A., Juarez, A., 2018b. Life history traits of the common cuttlefish, sepia officinalis linnaeus, 1758 in the Gulf of cadiz in the autumn-spring 2017-2018. Book of Abstracts of Cephalopod International Advisory Council Conference 2018 Cephalopod Research Across Scales: From Molecules to Ecosystems. Cephalopod International Advisory Council, St. Petersburg, p. 257.

Bañón, R., Otero, J., Campelos-Álvarez, J.M., Garazo, A., Alonso-Fernández, A., 2018. The traditional small-scale octopus trap fishery off the Galician coast (Northeastern Atlantic): historical notes and current fishery dynamics. Fish. Res. 206, 115-128. https://doi.org/10.1016/j.fishres.2018.05.005.

Barragán-Méndez, C., Sobrino, I., Marín-Rincón, A., Fernández-Boo, S., Costas, B., Mancera, J.M., Ruiz-Jarabo, I., 2019. Acute-stress biomarkers in three Octopodidae species after bottom trawling. Front. Physiol. 10, 784. https://doi.org/10.3389/ fphys.2019.00784.

I. Barratt , L. Allcock . Gonatus fabricii. The IUCN Red List of Threatened Species 2014 doi: 10.2305/IUCN.UK.2014-1.RLTS.T163186A981413.en 2014; e. T163186A981413 Downloaded on 12 April 2020

Barrett, C., Laptikhovsky, V., 2017. Distributions of squids on the shelf around the U.K. And some insights on population structures. In: Presentation at CephsInAction \& CIAC Meeting. Heraklion, Crete. https://www.youtube.com/watch?v=7V yBqG6p1uE.

Bengil, F., Bengil, E.G.T., Mavruk, S., Heral, O., Karaman, O.D., Ozaydin, O., 2019. Feeding ecology of four demersal shark species (Etmopterus spinax, Galeus melastomus, Scyliorhinus canicula and Squalus blainville) from the Eastern Aegean Sea. Turkish J. Fish. Aquat. Sci. 19, 475-484. https://doi.org/10.4194/1303-2712-v19_ $6 \_03$.

Bjorke, H., 2001. Predators of the squid Gonatus fabricii (Lichenstein) in the Norwegian Sea. Fish. Res. 52, 113-120.

Bloor, I.S.M., Attrill, M.J., Jackson, E.L., 2013. Chapter One - A Review of the Factors Influencing Spawning, Early Life Stage Survival and Recruitment Variability in the Common Cuttlefish (Sepia officinalis). Adv. Mar. Biol. 65, 1-65. https://doi.org/ 10.1016/B978-0-12-410498-3.00001-X.

Boyle, P.R., Boletzky, S.V., Clarke, M.R., 1996. Cephalopod populations: definition and dynamics. Philos. Trans. R. Soc. London. Ser. B Biol. Sci. 351, 985-1002. https://doi. org/10.1098/rstb.1996.0089.

Caddy, J.F., Rodhouse, P.G., 1998. Cephalopod and groundfish landings: evidence for ecological change in global fisheries. Rev. Fish Biol. Fish. 8, 431-444.

Capaz, J.C., Tunnah, L., MacCormack, T.J., Lamarre, S.G., Sykes, A.V., Driedzic, W.R., 2017. Hypoxic induced decrease in oxygen consumption in cuttlefish (Sepia officinalis) is associated with minor increases in Mantle Octopine but No changes in markers of protein turnover. Front. Physiol. 8, 344. https://doi.org/10.3389/ fphys.2017.00344.

Castellano, G.C., da Veiga, M.P.T., Mazzini, F.S., Vidal, E.A.G., Freire, C.A., 2018. Paralarvae of Octopus vulgaris Type II are stenohaline conformers: relationship to field distribution and dispersal. Hydrobiologia 808, 71-82. https://doi.org/ 10.1007/s10750-017-3458-y.

Ceriola, L., Milone, N., 2017. Growth and reproduction of the squid Illex coindetii Verany, 1839 in the southern Adriatic Sea, Central Mediterranean. Mediterr. Mar. Sci. 18, 107-120. https://doi.org/10.12681/mms.1682.

Çetinörge, E., Önsoy, B., 2018. Reproductive biology of Common octopus, octopus vulgaris cuvier, 1797 (octopoda: cephalopoda) from the eastern Mediterranean Sea. In: International Marine and Freshwater Sciences Meeting (MARFRESH2018). 18-21 October 2018. Antalya Turkey, p. 217.Available online at: https://docplayer.net /102270720-International-marine-freshwater-sciences-symposium-proceedings-mar fresh2018.html.

Cherel, Y., Ducatez, S., Fontaine, C., Richard, P., Guinet, C., 2008. Stable isotopes reveal the trophic position and mesopelagic fish diet of female southern elephant seals breeding on the Kerguelen Islands. Mar. Ecol. Prog. Ser. 370, 239-247. https://doi. org $/ 10.3354 /$ meps07673.

Ciércoles, C., García-Ruiz, C., González, M., De Urbina, J.O., López-González, N., Urra, J., Rueda, J.L., 2018. Molluscs collected with bottom otter trawl in the northern Alboran Sea: main assemblages, spatial distribution and environmental linkage. Mediterr. Mar. Sci. 19, 209-222. https://doi.org/10.12681/mms.2124.

Cozza, N., Bonani, W., Motta, A., Migliaresi, C., 2016. Evluation of alternative sources of collagen fractions from Loligo vulgaris squid mantle. Int. J. Biol. Macromol. 87, 504-513.

Dan, S., Iwasaki, H., Takasugi, A., Yamazaki, H., Hamasaki, K., 2018. An upwelling system for culturing common octopus paralarvae and its combined effect with supplying natural zooplankton on paralarval survival and growth. Aquaculture 495, 98-105. https://doi.org/10.1016/j.aquaculture.2018.05.036.

Dance, M.A., Bello, G., Furey, N.B., Rooker, J.R., 2014. Species-specific variation in cuttlebone $\delta 13 \mathrm{C}$ and $\delta 180$ for three species of Mediterranean cuttlefish. Mar. Biol. 161, 489-494. https://doi.org/10.1007/s00227-013-2346-x.

Davies, D., Nelson, K., 2018. Supporting Sustainable Sepia stocks. Report 2: the English Channel Fishery for Common Cuttlefish (Sepia Officinalis), 29 pp.. IFCA, Sussex https ://secure.toolkitfiles.co.uk/clients/34087/sitedata/files/Research/2-English-Ch annel-fishery-for-cuttlefish.pdf.

de la Chesnais, T., Fulton, E.A., Tracey, S.R., Pecl, G.T., 2019. The ecological role of cephalopods and their representation in ecosystem models. Rev. Fish Biol. Fish. 29, 313-334.

Dede, A., Salman, A., Tonay, A.M., 2016. Stomach contents of by-caught striped dolphins (Stenella coeruleoalba) in the eastern Mediterranean Sea. J. Mar. Biol. Assoc. U.K. 96, 869-875. https://doi.org/10.1017/S0025315415001538.

DeLaHoz, M.V., Sardà, F., Coll, M., Sáez, R., Mechó, A., Oliva, F., Ballesteros, M., Palomera, I., 2018. Biodiversity patterns of megabenthic non-crustacean invertebrates from an exploited ecosystem of the Northwestern Mediterranean Sea. Reg. Stud. Mar. Sci. 19, 47-68. https://doi.org/10.1016/j.rsma.2018.03.002.

Deryckere, A., Styfhals, R., Vidal, E.A.G., Almansa, E., Seuntjens, E., 2020. A practical staging atlas to study embryonic development of Octopus vulgaris under controlled laboratory conditions. BMC Dev. Biol. 20, 7. https://doi.org/10.1186/s12861-020 00212-6.

Di Poi, C., Darmaillacq, A.S., Dickel, L., Boulouard, M., Bellanger, C., 2013. Effects of perinatal exposure to waterborne fluoxetine on memory processing in the cuttlefish Sepia officinalis. Aquat. Toxicol. 132-133, 84-91. https://doi.org/10.1016/j. aquatox.2013.02.004

Di Poi, C., Bidel, F., Dickel, L., Bellanger, C., 2014. Cryptic and biochemical responses of young cuttlefish Sepia officinalis exposed to environmentally relevant concentrations 
of fluoxetine. Aquat. Toxicol. 151, 36-45. https://doi.org/10.1016/j. aquatox.2013.12.026.

Dorey, N., Melzner, F., Martin, S., Oberhänsli, F., Teyssié, J.-L., Bustamante, P., Gattuso, J.-P., Lacoue-Labarthe, T., 2013. Ocean acidification and temperature rise: effects on calcification during early development of the cuttlefish Sepia officinalis. Mar. Biol. 160, 2007-2022. https://doi.org/10.1007/s00227-012-2059-6.

Doubleday, Z.A., Connell, S.D., 2018. Weedy futures: can we benefit from the species that thrive in the marine Anthropocene? Front. Ecol. Environ. 16, 599-604. https://doi. org $/ 10.1002 /$ fee. 1973.

Doubleday, Z.A., Prowse, T.A.A., Arkhipkin, A., Pierce, G.J., Semmens, J., Steer, M., Leporati, S.C., Lourenço, S., Quetglas, A., Sauer, W., Gillanders, B.M., 2016. Global proliferation of cephalopods. Curr. Biol. 26, R406-R407. https://doi.org/10.1016/j. cub.2016.04.002.

Drerup, C., Cooke, G., 2019a. Cephalopod ID Guide for the North Sea. https://doi.org/ 10.5281 /zenodo. 2589266 .

Drerup, C., Cooke, G., 2019b. Cephalopod ID Guide for the Northeast Atlantic. https:// doi.org/10.5281/zenodo.2589228.

Drerup, C., Cooke, G., 2019c. Cephalopod ID Guide for the Mediterranean Sea. https:// doi.org/10.5281/zenodo.2589226.

Dulvy, N.K., Rogers, S.I., Jennings, S., Stelzenmüller, V., Dye, S.R., Skjoldal, H.R., 2008. Climate change and deepening of the North Sea fish assemblage: a biotic indicator of warming seas. J. Appl. Ecol. 45, 1029-1039. https://doi.org/10.1111/j.13652664.2008.01488.x.

Dursun, D., Eronat, E.G.T., Akalin, M., Salman, M.A., 2013. Reproductive biology of pink cuttlefish Sepia orbignyana in the Aegean Sea (eastern Mediterranean). Turkish J. Zool. 37, 576-581. https://doi.org/10.3906/zoo-1209-22.

Engelhard, G.H., van der Kooij, J., Righton, D.A., Jones, M.C., Pinnegar, J., 2018. Squid on the move in a marine climate change 'hotspot' and why it matters to fisheries and society. In: Book of Abstracts of 4th International Symposium on The Effects of Climate Change on the World'S Oceans. PICES Secretariat, Washington D.C. p..108

Falautano, M., Castriota, L., Cillari, T., Vivona, P., Finoia, M.G., Andaloro, F., 2018. Characterization of artisanal fishery in a coastal area of the Strait of Sicily (Mediterranean Sea): evaluation of legal and IUU fishing. Ocean Coast. Manag. 151, 77-91. https://doi.org/10.1016/j.ocecoaman.2017.10.022.

Fang, Z., Chen, X., 2018. Statolith-based species identification methods for ommastrephidae species. Proceedings - 2017 10th International Congress on Image and Signal Processing, BioMedical Engineering and Informatics, CISP-BMEI 2017 1-6. https://doi.org/10.1109/CISP-BMEI.2017.8302015.

Fang, Z., Chen, X., Lu, H.J., Li, J., Liu, B.L., 2014a. Morphology and growth of beaks in two cohorts for neon flying squid (Ommastrephes bartramii) in the North Pacific Ocean. Acta Ecol. Sin. 34, 5405-5415. https://doi.org/10.5846/stxb201301110083.

Fang, Z., Liu, B., Li, J., Su, H., Chen, X., 2014b. Stock identification of neon flying squid (Ommastrephes bartramii) in the North Pacific Ocean on the basis of beak and statolith morphology. Sci. Mar. 78, 239-248. https://doi.org/10.3989/ scimar.03991.06a.

Fang, Z., Chen, X., Li, J., Liu, B., Thompson, K., Chen, Y., Hu, F., 2016a. Age, growth, and population structure of the red flying squid (Ommastrephes bartramii) in the North Pacific Ocean, determined from beak microstructure. Fish. Bull. (Wash. D. C.) 114 34-44. https://doi.org/10.7755/FB.114.1.3.

Fang, Z., Liu, B., Chen, X., Jin, Y., Li, J., Chen, Y., 2016b. Sexual asynchrony in the development of beak pigmentation for the neon flying squid Ommastrephes bartramii in the North Pacific Ocean. Fish. Sci. 82, 737-746. https://doi.org/10.1007/s12562016-1011-y.

Fang, Z., Thompson, K., Jin, Y., Chen, X., Chen, Y., 2016c. Preliminary analysis of beak stable isotopes ( $\delta 13 \mathrm{C}$ and $\delta 15 \mathrm{~N}$ ) stock variation of neon flying squid, Ommastrephes bartramii, in the North Pacific Ocean. Fish. Res. 177, 153-163. https://doi.org/ 10.1016/j.fishres.2016.01.011.

Fang, Z., Chen, X., Su, H., Thompson, K., Chen, Y., 2017. Evaluation of stock variation and sexual dimorphism of beak shape of neon flying squid, Ommastrephes bartramii, based on geometric morphometrics. Hydrobiologia 784, 367-380. https://doi.org/ 10.1007/s10750-016-2898-0.

Feng, Y., Chen, X., Liu, Y., 2016. The effects of changing spatial scales on spatial patterns of CPUE for Ommastrephes bartramii in the northwest Pacific Ocean. Fish. Res. 183, 1-12. https://doi.org/10.1016/j.fishres.2016.05.006Feng.

Fernández-Álvarez, F.Á., Martins, C.P.P., Vidal, E.A.G., Villanueva, R., 2017. Towards the identification of the ommastrephid squid paralarvae (Mollusca: cephalopoda): morphological description of three species and a key to the north-east Atlantic species. Zool. J. Linn. Soc. 180, 268-287. https://doi.org/10.1111/zoj.12496.

Fernández-Álvarez, F.Á., Braid, H.E., Nigmatullin, C.M., Bolstad, K.S.R., Haimovici, M., Sánchez, P., Sajikumar, K.K., Ragesh, N., Villanueva, R., 2020. Global biodiversity of the genus Ommastrephes (Ommastrephidae: cephalopoda): an allopatric cryptic species complex. Zool. J. Linn. Soc. 1-23. https://doi.org/10.1093/zoolinnean/ zlaa014.

Feyjoo, P., Cabanellas-Reboredo, M., Calvo-Manazza, M., Morales-Nín, B., HernándezUrcera, J., Garci, M.E., González, Á.F., Guerra, Á, 2016. New insights on the external features of egg capsules and embryo development in the squid Loligo vulgaris. J. Nat. Hist. 50, 543-555. https://doi.org/10.1080/00222933.2015.1062932.

Fiorentino, F., Massutì, E., Tinti, F., Somarakis, S., Garofalo, G., Russo, T., Facchini, M.T., Carbonara, P., Kapiris, K., Tugores, P., Cannas, R., Tsigenopoulos, C., Patti, B., Colloca, F., Sbrana, M., Mifsud, R., Valavanis, V., Spedicato, M.T., 2014. Stock Units: Identification of Distinct Biological Units (stock Units) for Different Fish and Shellfish Species and Among Different GFCM-GSA. STOCKMED Deliverable 03: FINAL REPORT. September 2014, 310 Pp. Specific Contract No 7 (SI2.642234). htt ps://ec.europa.eu/fisheries/documentation/studies/stockmed/.
Franco-Santos, R.M., Perales-Raya, C., Almansa, E., De Troch, M., Garrido, D., 2016. Beak microstructure analysis as a tool to identify potential rearing stress for Octopus vulgaris paralarvae. Aquac. Res. 47, 3001-3015. https://doi.org/10.1111/are.12753.

Franjevic, D., Skaramuca, D., Katavic, V., Rajevic, N., Skaramuca, B., 2015. Genetic identification of a rare record of Ommastrephes bartramii (Cephalopoda: ommastrephidae) from the Eastern Adriatic Sea. Folia Biol. (Krakow) 63, 19-23. https://doi.org/10.3409/fb63_1.19.

Gajić, A., Dedić, N., Kahrić, A., 2014. First note on the Musky Octopus, Eledone moschata (Lamarck, 1798) (Cephalopoda: octopoda: octopodidae), in the Neum Bay. Udruženje za Inventar. i zaštitu životinja 10, 1-5.

García-Fernández, P., Prado-Alvarez, M., Nande, M., Garcia dela serrana, D., PeralesRaya, C., Almansa, E., Varó, I., Gestal, C., 2019. Global impact of diet and temperature over aquaculture of Octopus vulgaris paralarvae from a transcriptomic approach. Sci. Rep. 9, 10312. https://doi.org/10.1038/s41598-019-46492-2.

García-Martínez, M., del, C., Moya, F., González, M., Torres, P., Farzaneh, S., VargasYáñez, M., 2018. Comparative pattern of Octopus vulgaris life cycle with environmental parameters in the Northern Alboran Sea (Western Mediterranean Sea). Turkish J. Fish. Aquat. Sci. 18, 247-257. https://doi.org/10.4194/1303-2712v18 204.

Garrido, D., Navarro, J.C., Perales-Raya, C., Nande, M., Martín, M.V., Iglesias, J., Bartolomé, A., Roura, A., Varó, I., Otero, J.J., González, F., Rodríguez, C., Almansa, E., 2016. Fatty acid composition and age estimation of wild Octopus vulgaris paralarvae. Aquaculture 464, 564-569. https://doi.org/10.1016/j. aquaculture.2016.07.034.

Garrido, D., Martín, M.V., Rodríguez, C., Iglesias, J., Navarro, J.C., Estévez, A., Hontoria, F., Becerro, M., Otero, J.J., Pérez, J., Varó, I., Reis, D.B., Riera, R., Sykes, A.V., Almansa, E., 2018. Meta-analysis approach to the effects of live prey on the growth of Octopus vulgaris paralarvae under culture conditions. Rev. Aquac. 10, 3-14. https://doi.org/10.1111/raq.12142.

Gasalla, M.A., Rodrigues, A.R., Postuma, F.A., 2010. The trophic role of the squid Loligo plei as a keystone species in the South Brazil Bight ecosystem. ICES J. Mar. Sci. 67, 1413-1424.

Gebhardt, K., Knebelsberger, T., 2015. Identification of cephalopod species from the North and Baltic Seas using morphology, COI and 18S rDNA sequences. Helgol. Mar. Res. 69, 259-271. https://doi.org/10.1007/s10152-015-0434-7.

Gestal, C., Pascual, S., Guerra, Á., Fiorito, G., Vieites, J.M., 2019. Handbook of pathogens and diseases in cephalopods. Handbook of Pathogens and Diseases in Cephalopods. Springer. https://doi.org/10.1007/978-3-030-11330-8.

Giansante, C., Conte, A., Giovannini, A., Ferri, N., Castriota, L., Andaloro, F., 2014. Assessment of the effect of the climate variations of coastal surface water and study of Sepia officinalis spawing. Vet. Ital. 50, 87-97. https://doi.org/10.12834/ VetIt.2004.52.

Golikov, A.V., 2014. Distribution and Reproductive Biology of the Decapod Cephalopods (Sepiolida, Teuthida) in the Barents Sea and Adjacent Areas. PhD Thesis. Kazan Federal University, 236 pp.

Golikov, A.V., Sabirov, R.M., Lubin, P.A., Jørgensen, L.L., Beck, I.M., 2014. The northernmost record of Sepietta oweniana (Cephalopoda: sepiolidae) and comments on boreo-subtropical cephalopod species occurrence in the Arctic. Mar. Biodivers. Rec. 7, E58. https://doi.org/10.1017/S1755267214000645.

Golikov, A.V., Sabirov, R.M., Lubin, P.A., 2017. First assessment of biomass and abundance of cephalopods Rossia palpebrosa and Gonatus fabricii in the Barents Sea. J. Mar. Biol. Assoc. U.K. 97, 1605-1616. https://doi.org/10.1017/ S0025315416001004.

Golikov, A.V., Ceia, F.R., Sabirov, R.M., Zaripova, Z.I., Blicher, M.E., Zakharov, D.V., Xavier, J.C., 2018. Ontogenetic changes in stable isotope ( $\delta 13 \mathrm{C}$ and $\delta 15 \mathrm{~N})$ values in squid Gonatus fabricii (Cephalopoda) reveal its important ecological role in the Arctic. Mar. Ecol. Prog. Ser. 606, 65-78. https://doi.org/10.3354/meps12767.

Golikov, A.V., Blicher, M.E., Jørgensen, L.L., Walkusz, W., Zakharov, D.V., Zimina, O.L., Sabirov, R.M., 2019. Reproductive biology and ecology of the boreoatlantic armhook squid Gonatus fabricii (Cephalopoda: gonatidae). J. Molluscan Stud. 5 (3), 341-353. https://doi.org/10.1093/mollus/eyz023.

González, A.F., Castro, B.G., Guerra, A., 1996. Age and growth of the short-finned squid Illex coindetii in Galician waters (NW Spain) based on statolith analysis. ICES J. Mar. Sci. 53, 802-810.

Gras, M., Roel, B.A., Coppin, F., Foucher, E., Robin, J.P., 2014. A two-stage biomass model to assess the English Channel cuttlefish (Sepia officinalis L.) stock. ICES J. Mar. Sci. 71, 2457-2468. https://doi.org/10.1093/icesjms/fsu081.

Green, C.P., Robertson, S.G., Hamer, P.A., Virtue, P., Jackson, G.D., Moltschaniwskyj, N. A., 2015. Combining statolith element composition and fourier shape data allows discrimination of spatial and temporal stock structure of arrow squid (Nototodarus gouldi). Can. J. Fish. Aquat. Sci. 72, 1609-1618. https://doi.org/10.1139/cjfas2014-0559.

Guerra, Á., Hernández-Urcera, J., Garci, M.E., Sestelo, M., Regueira, M., González, Á.F., Cabanellas-Reboredo, M., Calvo-Manazza, M., Morales-Nin, B., 2014. Dwellers in dens on sandy bottoms: ecological and behavioural traits of Octopus vulgaris. Sci. Mar. 78, 405-414. https://doi.org/10.3989/scimar.04071.28f.

Hernández-Urcera, J., Garci, M.E., Roura, Á., González, Á.F., Cabanellas-Reboredo, M., Morales-Nin, B., Guerra, Á., 2014. Cannibalistic behavior of octopus (Octopus vulgaris) in the wild. J. Comp. Psychol. 128, 427-430. https://doi.org/10.1037/ a0036883.

Hu, G., Fang, Z., Liu, B., Chen, X., Staples, K., Chen, Y., 2018. Using different standardized methods for species identification: a case study using beaks from three ommastrephid species. J. Ocean Univ. China 17, 355-362. https://doi.org/10.1007/ s11802-018-3441-x. 
Hunsicker, M.E., Essington, T.E., Watson, R., Sumaila, U.R., 2010. The contribution of cephalopods to global marine fisheries: can we have our squid and eat them too? Fish Fish. Oxf. (Oxf) 11, 421-438.

ICES, 2020. Working Group on Cephalopod Fisheries and Life History (WGCEPH; outputs from 2019 meeting). ICES Scientific Reports 2 (46). https://doi.org/10.17895/ices. pub.6032, $121 \mathrm{pp}$.

Iglesias, J., Fuentes, L., Villanueva, R., 2014. Cephalopod Culture. Springer Science \& Business Media, Dordrecht. https://doi.org/10.1007/978-94-017-8648-5.

Iglesias, P., Picón, P., Nande, M., Lago, M.J., Otero, J.J., Trujillo, V., Iglesias, J., 2016. Effect of low salinity on survival and ingested food of the common octopus, Octopus vulgaris Cuvier, 1797. J. Appl. Aquac. 28, 267-271. https://doi.org/10.1080/ 10454438.2016.1190953.

Ikica, Z., Vuković, V., Đurović, M., Joksimović, A., Krstulović ŠIfner, S., 2014. Analysis of beak morphometry of the horned octopus Eledone cirrhosa, Lamarck 1798 (Cephalopoda: octopoda), in the south-eastern Adriatic Sea. Acta Adriat. 55, 43-56.

Jereb, P., Roper, C.F.E., Norman, M.D., 2014. In: Finn, Julian K. (Ed.), Cephalopods of the World. An Annotated and Illustrated Catalogue of Cephalopod Species Known to Date, Volume 3. Octopods and Vampire Squids. FAO Species Catalogue for Fishery Purposes, Rome, 370 pp. http://www.fao.org/3/a-i3489e.pdf.

Jereb, P., Allcock, A.L., Lefkaditou, E., Piatkowski, U., Hastie, L.C., Pierce, G., 2015. Cephalopod biology and fisheries in Europe: II. Species accounts. In: ICES Cooperative Research Report. Internationa Council for the Exploration of the Sea, Copenhagen, pp. 1-360.

Jin, Y., Liu, B., Li, J., Chen, X., 2017. Identification of three common Loliginidae squid species in the South China Sea by analyzing hard tissues with geometric outline method. J. Ocean Univ. China 16, 840-846. https://doi.org/10.1007/s11802-017. 3218-7.

Joubin, L., 1895. Contribution à l'étude des Céphalopodes de l'Atlantique Nord. Resultats des Campagnes Scientifiques Accomplies par le Prince Albert I, Monaco 9, $1-63$.

Karim, S., Aoutini, A., Taleb, M., El hajjaji, F., Belbachir, C., Rahhou, I., Achmit, M., Hammouti, B., 2019. Evaluation of heavy metal concentrations in seven commercial marine fishes caught in the Mediterranean coast of Morocco and their associated health risks to consumers. J. environ. biotechnol. res. 8 (1), 1-13. https://doi.org/ 10.5281/ZENODO.2529361.

Kato, Y., Sakai, M., Nishikawa, H., Igarashi, H., Ishikawa, Y., Vijai, D., Sakurai, Y., Wakabayshi, T., Awaji, T., 2016. Stable isotope analysis of the gladius to investigate migration and trophic patterns of the neon flying squid (Ommastrephes bartramii). Fish. Res. 173, 169-174. https://doi.org/10.1016/j.fishres.2015.09.016.

Katsanevakis, S., Verriopoulos, G., 2004. Den ecology of Octopus vulgaris Cuvier, 1797, on soft sediment: availability and types of shelter. Sci. Mar. 68, 147-157.

Keller, S., Valls, M., Hidalgo, M., Quetglas, A., 2014. Influence of environmental parameters on the life-history and population dynamics of cuttlefish Sepia officinalis in the western Mediterranean. Estuar. Coast. Shelf Sci. 145, 31-40. https://doi.org/ 10.1016/j.ecss.2014.04.016.

Keller, S., Hidalgo, M., Álvarez-Berastegui, D., Bitetto, I., Casciaro, L., Cuccu, D., Esteban, A., Garofalo, G., Gonzalez, M., Guijarro, B., Josephides, M., Jadaud, A., Lefkaditou, E., Maiorano, P., Manfredi, C., Marceta, B., Micallef, R., Peristeraki, P., Relini, G., Sartor, P., Spedicato, M.T., Tserpes, G., Quetglas, A., 2017a. Demersal cephalopod communities in the Mediterranean: a large-scale analysis. Mar. Ecol. Prog. Ser. 584, 105-118. https://doi.org/10.3354/meps12342.

Keller, S., Quetglas, A., Puerta, P., Bitetto, I., Casciaro, L., Cuccu, D., Esteban, A., Garcia, C., Garofalo, G., Guijarro, B., Josephides, M., Jadaud, A., Lefkaditou, E., Maiorano, P., Manfredi, C., Marceta, B., Micallef, R., Peristeraki, P., Relini, G., Sartor, P., Spedicato, M.T., Tserpes, G., Hidalgo, M., 2017b. Environmentally driven synchronies of Mediterranean cephalopod populations. Prog. Oceanogr. 152, 1-14. https://doi.org/10.1016/j.pocean.2016.12.010.

Kousteni, V., Karachle, P.K., Megalofonou, P., Lefkaditou, E., 2018. Cephalopod prey of two demersal sharks caught in the Aegean Sea (eastern Mediterranean). J. Mar. Biol. Assoc. U.K. 98, 81-88. https://doi.org/10.1017/S002531541700159X.

Kwon, I., Moon, S., Lee, H., Lee, J., Kim, T., 2019. Growth of juvenile common octopus (Octopus vulgaris) in Korean waters is affected by shelter type. J. Aquac. Eng. Fish. Res. 85, 1-8. https://doi.org/10.1016/j.aquaeng.2019.01.002.

Lacoue-Labarthe, T., Pabic, C.Le, Bustamante, P., 2016. Ecotoxicology of early-life stages in the common cuttlefish Sepia officinalis: review and perspectives. Vie Milieu 66, 65-79.

Laptikhovsky, V., Ouréns, R., 2017. Identification Guide for Shelf Cephalopods in the UK Waters (North Sea, the English Channel, Celtic and Irish Seas). Ver. 2. Cefas, Lowestoft.

Laptikhovsky, V., Barret, C., Oesterwind, D., 2018. Summer-spawning loligo vulgaris in the North Sea: the story of a disappeared stock or changed reproductive patterns? Book of Abstracts of Cephalopod International Advisory Council Conference 2018 Cephalopod Research Across Scales: From Molecules to Ecosystems. Cephalopod International Advisory Council, St. Petersburg, p. 159.

Laptikhovsky, V., Barrett, C., Firmin, C., Ouréns, R., 2019. Adaptations of the common cuttlefish Sepia officinalis $\mathrm{L}$. To cold water reproduction in the english channel. J. Shellfish Res. 38, 629-634. https://doi.org/10.2983/035.038.0314.

Lauria, V., Garofalo, G., Gristina, M., Fiorentino, F., 2016. Contrasting habitat selection amongst cephalopods in the Mediterranean Sea: when the environment makes the difference. Mar. Environ. Res. 119, 252-266. https://doi.org/10.1016/j. marenvres.2016.06.011.

Le Pabic, C., Goux, D., Guillamin, M., Safi, G., Lebel, J.M., Koueta, N., Serpentini, A., 2014. Hemocyte morphology and phagocytic activity in the common cuttlefish (Sepia officinalis). Fish Shellfish Immun. 40, 362-373. https://doi.org/10.1016/j. fsi.2014.07.020.
Le Pabic, C., Caplat, C., Lehodey, J.P., Dallas, L., Koueta, N., 2015. Physiological perturbations in juvenile cuttlefish Sepia officinalis induced by subchronic exposure to dissolved zinc. Mar. Pollut. Bull. 95, 678-687. https://doi.org/10.1016/j. marpolbul.2015.02.018.

Lefkaditou, E., Peristeraki, P., Koutsoubas, D., Ok, M., Bariche, M., Kontoyiannis, H. 2013. On the association of ommastrephes bartramii (teuthoidea: cephalopoda) spawning ground range and changing environmental conditions in the eastern Mediterranean. Book of Abstracts of MARBIGEN Conference 2013 on "Mediterranean Marine Biodiversity in View of Climatic Change and the Invasion of Alien Species". Hellenic Center for Marine Research, Heraklion, p. 45.

Lin, L., Jintao, W., Xinjun, C., Huajie, L., 2019a. Standardizing CPUE of Ommastrephes bartramii in the Northwest Pacific Ocean based on environmental factors of habitat. Haiyang Xuebao 41, 134-141.

Lin, D., Xuan, S., Chen, Z., Chen, X., 2019b. The ovarian development, fecundity and hypothesis on spawning pattern of common cuttlefish Sepia officinalis off Mauritania. Fish. Res. 210, 193-197. https://doi.org/10.1016/j.fishres.2018.08.003.

Lishchenko, F., Lishchenko, A., Bizikov, V., 2017. Statolith shape variability of berryteuthis magister. In: Ponte, G., Lishchenko, F., Lischchenko, A. (Eds.), Cephalopod Science from Biology to WelfareCOST Action Fa1301 "CephsInAction" \& Cephalopod International Advisory Council 'CIAC', Heraklion, p. 8.

Liu, B.L., Chen, X.J., Chen, Y., Hu, G.Y., 2015. Determination of squid age using upper beak rostrum sections: technique improvement and comparison with the statolith. Mar. Biol. 162, 1685-1693. https://doi.org/10.1007/s00227-015-2702-0.

López, N., Navarro, J., Barría, C., Albo-Puigserver, M., Coll, M., Palomera, I., 2016. Feeding ecology of two demersal opportunistic predators coexisting in the northwestern Mediterranean Sea. Estuar. Coast. Shelf Sci. 175, 15-23. https://doi. org/10.1016/j.ecss.2016.03.007.

Malhomme, F., Duhem, E., Porcher, Z., Sobrino, I., Robin, J.-P., 2015. English channel loliginid squid stocks: surplus production models used to estimate population biomass and stock status in a context of variable environment. Book of Abstracts of Cephalopod International Advisory Council Conference 2015 Recent Advances in Cephalopod Science. Cephalopod International Advisory Council, Hakodate, p. 79.

Martínez-Baena, F., Navarro, J., Albo-Puigserver, M., Palomera, I., Rosas-Luis, R., 2016. Feeding habits of the short-finned squid Illex coindetii in the western Mediterranean Sea using combined stomach content and isotopic analysis. J. Mar. Biol. Assoc. U.K. 96, 1235-1242. https://doi.org/10.1017/S0025315415001940.

Martínez-Baños, P., Maynou, F., 2018. Reducing discards in trammel net fisheries with simple modifications based on a guarding net and artificial light: contributing to marine biodiversity conservation. Sci. Mar. 82, 9-18. https://doi.org/10.3989/ scimar.04710.03A.

Martins, C.P.P., Fernández-Álvarez, F., Villanueva, R., 2018. Invertebrate predation on egg masses of the European cuttlefish, Sepia officinalis: an experimental approach. Estuar. Coast. Shelf Sci. 200, 437-448. https://doi.org/10.1016/j.ecss.2017.11.016.

Mather, J.A., 1982. Choice and competition: their effects on occupancy of Shell Homes by Octopus joubini. Mar. Behav. Physiol. 8, 285-293. https://doi.org/10.1080/ 10236248209387025.

McKeown, N.J., Robin, J.P., Shaw, P.W., 2015. Species-specific PCR-RFLP for identification of early life history stages of squid and other applications to fisheries research. Fish. Res. 167, 207-209. https://doi.org/10.1016/j.fishres.2015.02.007.

Melli, V., Riginella, E., Nalon, M., Mazzoldi, C., 2014. From trap to nursery. Mitigating the impact of an artisanal fishery on cuttlefish offspring. PLoS One 9, e90542. https://doi.org/10.1371/journal.pone.0090542.

Merchant, N.D., Brookes, K.L., Faulkner, R.C., Bicknell, A.W.J., Godley, B.J., Witt, M.J., 2016. Underwater noise levels in UK waters. Sci. Rep. 6, 36942. https://doi.org/ 10.1038/srep36942.

Mereu, M., Agus, B., Cannas, R., Cau, A., Coluccia, E., Cuccu, D., 2015. Mark-recapture investigation on Octopus vulgaris specimens in an area of the central western Mediterranean Sea. J. Mar. Biol. Assoc. U.K. 95, 131-138. https://doi.org/10.1017/ S002531541400112X.

Mion, M., Piras, C., Giovanardi, O., 2014. Dinamiche Di Crescita Di Mullus barbatus L., 1758 E Sepia officinalis L., 1758 in Relazione Al "fermo Pesca Biologico". (Growth Dynamics of Mullus barbatus L., 1758 and Sepia officinalis L., 1758 in Relation to the Summer Trawling Ban), in: 45 Congresso Della Società Italiana Di Biologia Marina. Societa Italiana di Biologia Marina, Venezia, pp. 289-290.

Morales, A.E., Cardenete, G., Hidalgo, M.C., Garrido, D., Martín, M.V., Almansa, E., 2017. Time course of metabolic capacities in paralarvae of the common octopus, Octopus vulgaris, in the first stages of life. Searching biomarkers of nutritional imbalance. Front. Physiol. 8, 427. https://doi.org/10.3389/fphys.2017.00427.

Moreno, A., Lourenço, S., Pereira, J., Gaspar, M.B., Cabral, H.N., Pierce, G.J., Santos, A. M.P., 2014a. Essential habitats for pre-recruit Octopus vulgaris along the Portuguese coast. Fish. Res. 152, 74-85. https://doi.org/10.1016/j.fishres.2013.08.005.

Moreno, A., Chaves, C., Lourenço, S., Mendes, H., Pereira, J., 2014b. Nursery and spawning grounds of the squid loligo vulgaris on the Portuguese shelf. In: ICES Annual Science Conference: Sustainability in a Changing Ocean. International Council for the Exploration of the Sea. Coruña, pp. 18-19.

Mouritsen, O.G., Styrbæk, K., 2018. Cephalopod gastronomy - a promise for the future. Front. Commun. 3, 38 https://doi.org/doi: 10.3389/fcomm.2018.00038.

Nadarajah, S.K., Vijayarai, R., Mani, J., 2016. Therapeutic significance of Loligo vulgaris (Lamarck, 1798) ink extract: a biomedical approach. Pharmacognosy Res. 9, S105-S109. https://doi.org/10.4103/pr.pr_81_17.

Nande, M., Iglesias, J., Domingues, P., Pérez, M., 2017. Effect of temperature on energetic demands during the last stages of embryonic development and early life of Octopus vulgaris (Cuvier, 1797) paralarvae. Aquac. Res. 48, 1951-1961. https://doi. org/10.1111/are.13032. 
Nande, M., Domingues, P., Rosas, C., 2018. Effects of temperature on the embryonic development of Octopus vulgaris. J. Shellfish Res. 37, 1013. https://doi.org/10.2983/ 035.037.0512.

O’Brien, C.E., Jozet-Alves, C., Mezrai, N., Bellanger, C., Darmaillacq, A.S., Dickel, L., 2017a. Maternal and embryonic stress influence offspring behavior in the cuttlefish Sepia officinalis. Front. Physiol. 8, 981. https://doi.org/10.3389/fphys.2017.00981.

O'Brien, C.E., Mezrai, N., Darmaillacq, A.S., Dickel, L., 2017b. Behavioral development in embryonic and early juvenile cuttlefish (Sepia officinalis). Dev. Psychobiol. 59, 145-160. https://doi.org/10.1002/dev.21476.

O'Brien, C.E., Roumbedakis, K., Winkelmann, I.E., 2018. The current state of cephalopod science and perspectives on the most critical challenges ahead from three earlycareer researchers. Front. Physiol. 9, 700. https://doi.org/10.3389/ fphys.2018.00700.

Oesterwind, D., Schaber, M., 2020. First evidence of Illex coindetii (Vérany, 1839) in the Baltic Sea and the Kattegat. Thalass. An Int. J. Mar. Sci. 36, 143-147. https://doi. org/10.1007/s41208-019-00178-8.

Oesterwind, D., ter Hofstede, R., Harley, B., Brendelberger, H., Piatkowski, U., 2010. Biology and meso-scale distribution patterns of North Sea cephalopods. Fish. Res. 106, 141-150. https://doi.org/10.1016/j.fishres.2010.06.003.

Oesterwind, D., Piatkowski, U., Brendelberger, H., 2015. On distribution, size and maturity of shortfin squids (Cephalopoda, Ommastrephidae) in the North Sea. Mar. Biol. Res. 11, 188-196. https://doi.org/10.1080/17451000.2014.894246.

Oesterwind, D., Bobowski, B., Brunsch, A., Visconti, V., Laptikhovsky, V., Barrett, C., 2019. Trial study about age reading of North Sea squids. Working document. Interim Report of the Working Group on Cephalopod Fisheries and Life History (WGCEPH) International Council for the Exploration of the Sea, San Sebastian, pp. 188-194.

Oesterwind, D., Bobowski, B.T.C., Brunsch, A., Laptikhovsky, V., van Hal, R., Sell, A.F. Pierce, G.J., 2020. First evidence of a new spawning stock of Illex coindetii in the North Sea (NE-Atlantic). Fish. Res. 221, 105384 https://doi.org/10.1016/j. fishres.2019.105384.

Oliveira, C., Grano-Maldonado, M., Gonçalves, R., Frias, P., Sykes, A., 2017. Preliminary results on the daily and seasonal rhythms of cuttlefish Sepia officinalis (Linnaeus, 1758) locomotor activity in Captivity. Fishes 2, 1-9. https://doi.org/10.3390/ fishes 2030009 .

Olmos-Pérez, L., Roura, Á., Pierce, G.J., Boyer, S., González, Á.F., 2017. Diet composition and variability of wild Octopus vulgaris and Alloteuthis media (Cephalopoda) paralarvae through a metagenomic lens. Front. Physiol. 8, 321. https://doi.org/ 10.3389/fphys.2017.00321.

Otero, J., Álvarez-Salgado, X.A., González, Á.F., Souto, C., Gilcoto, M., Guerra, Á., 2016 Wind-driven upwelling effects on cephalopod paralarvae: octopus vulgaris and Loliginidae off the Galician coast (NE Atlantic). Prog. Oceanogr. 141, 130-143. https://doi.org/10.1016/j.pocean.2015.12.008.

Palas, S., Pita, P., 2015. La pesca recreativa de cefalópodos en la ría de vigo: aspectos ecológicos, sociales y económicos. In: Méndez, Rey, M, Fernández Casal, J, Lodeiros, C, Guerra D.íaz (Eds.), XVIII Foro Dos Recursos Mariños E Da Acuicultura Das Rías Galegas. Universidade de Santiago de Compostela, A Coruña, pp. 1-10.

Palas, S., Villasante, S., Pita, P., 2017. Combining fishers' knowledge and cost-effective monitoring tools in the management of marine recreational fisheries: a case study of the squid and cuttlefish fishery of the Ría of Vigo (NW Spain). Fish. Manag. Ecol. 24, 469-477. https://doi.org/10.1111/fme.12255.

Panetta, D., Solomon, M., Buresch, K., Hanlon, R.T., 2017. Small-scale rearing of cuttlefish (Sepia officinalis) for research purposes. Mar. Freshw. Behav. Physiol. 50, 115-124. https://doi.org/10.1080/10236244.2017.1343631.

Pardo-Gandarillas, M.C., Torres, F.I., Fuchs, D., Ibáñez, C.M., 2018. Updated molecular phylogeny of the squid family Ommastrephidae: insights into the evolution of spawning strategies. Mol. Phylogenet. Evol. 120, 212-217. https://doi.org/10.1016/ j.ympev.2017.12.014.

Penicaud, V., Lacoue-Labarthe, T., Bustamante, P., 2017. Metal bioaccumulation and detoxification processes in cephalopods: a review. Environ. Res. 155, 123-133. https://doi.org/10.1016/j.envres.2017.02.003.

Perales-Raya, C., Jurado-Ruzafa, A., Bartolomé, A., Duque, V., Carrasco, M.N., FraileNuez, E., 2014a. Age of spent Octopus vulgaris and stress mark analysis using beaks of wild individuals. Hydrobiologia 725, 105-114. https://doi.org/10.1007/s10750013-1602-x.

Perales-Raya, C., Almansa, E., Bartolomé, A., Felipe, B.C., Iglesias, J., Sánchez, F.J., Carrasco, J.F., Rodríguez, C., 2014b. Age validation in Octopus vulgaris beaks across the full ontogenetic range: beaks as recorders of life events in octopuses. J. Shellfish Res. 33, 481-493. https://doi.org/10.2983/035.033.0217.

Perales-Raya, C., Nande, M., Roura, A., Bartolome, A., Gestal, C., Otero, J.J., GarcíaFernández, P., Almansa, E., 2018. Comparative study of age estimation in wild and cultured Octopus vulgaris paralarvae: effect of temperature and diet. Mar. Ecol. Prog. Ser. 598, 247-259. https://doi.org/10.3354/meps12218.

Pereira, F., Vasconcelos, P., Moreno, A., Gaspar, M.B., 2019. Catches of Sepia officinalis in the small-scale cuttlefish trap fishery off the Algarve coast (southern Portugal). Fish. Res. 214, 117-125. https://doi.org/10.1016/j.fishres.2019.01.022.

Pierce, G.J., Allcock, L., Bruno, I., Bustamante, P., González, A.F., Guerra, A., Jereb, P., Lefkaditou, E., Malham, S., Moreno, A., Pereira, J., Piatkowski, U., Rasero, M., Sánchez, P., Santos, M.B., Santurtún, M., Seixas, S., Sobrino, I., Villanueva, R., 2010. Cephalopod Biology and Fisheries in Europe. Co-Operative Research Report 303, International Council for the Exploration of the Sea, 175 pp. ISBN 978-87-7482-078079.

Pilar-Fonseca, T., Pereira, J., Campos, A., Moreno, A., Fonseca, P., Afonso-Dias, M., 2014 VMS-based fishing effort and population demographics for the European squid (Loligo vulgaris) off the Portuguese coast. Hydrobiologia 725, 137-144. https://doi. org/10.1007/s10750-013-1736-x.
Puerta, P., Hidalgo, M., Gonzalez, M., Esteban, A., Quetglas, A., 2014a. Role of hydroclimatic and demographic processes on the spatio-temporal distribution of cephalopods in the western Mediterranean. Mar. Ecol. Prog. Ser. 514, 105-118. https://doi.org/10.3354/meps10972.

Puerta, P., Quetglas, A., Hidalgo, M., 2014b. Modelling seasonal variability of cephalopod abundances of three contrasting species from Western Mediterranean Sea. ICES CM, 2014/P:02.

Puerta, P., Hunsicker, M.E., Quetglas, A., Álvarez-Berastegui, D., Esteban, A., González, M., Hidalgo, M., 2015. Spatially explicit modeling reveals cephalopod distributions match contrasting trophic pathways in the Western Mediterranean Sea. PLoS One 10, e0133439. https://doi.org/10.1371/journal.pone.0133439.

Puerta, P., Quetglas, A., Hidalgo, M., 2016. Seasonal variability of cephalopod populations: a spatio-temporal approach in the Western Mediterranean Sea. Fish. Oceanogr. 25, 373-389. https://doi.org/10.1111/fog.12159.

Querol, P., Gairin, I., Guerao, G., Monge, R., Jover, M., Tomas, A., 2015. Effect of two extruded diets with different fish and squid meal ratio on growth, digestibility and body composition of Octopus vulgaris (Cuvier, 1797). Aquac. Res. 46, 2481-2489. https://doi.org/10.1111/are.12407.

Quetglas, A., Valls, M., Ordines, F., de Mesa, A., Olivar, M.P., Keller, S., Massutí, E., 2014. Structure and dynamics of cephalopod assemblages in the water column on shelf-break and slope grounds of the western Mediterranean. J. Mar. Syst. 138, 150-159. https://doi.org/10.1016/j.jmarsys.2013.11.015.

Quetglas, A., Valls, M., Capezzuto, F., Casciaro, L., Casciaro, L., Cuccu, D., González, M., Ikica, Z., Krstulović Šifner, S., Lauria, V., Lefkaditou, E., Peristeraki, P., Piccinetti, C., Vidoris, P., Keller, S., 2019. Long-term spatiotemporal dynamics of cephalopod assemblages in the Mediterranean Sea. Sci 83S1, 33-42. https://doi.org/10.3989/ scimar.04841.20A.

Quinteiro, J., Rodríguez-Castro, J., Rey-Méndez, M., González-Henríquez, N., 2020. Phylogeography of the insular populations of common octopus, Octopus vulgaris Cuvier, 1797, in the Atlantic Macaronesia. PLoS One 15, e0230294. https://doi.org/ 10.1371/journal.pone.0230294.

Raimundo, J., Pereira, P., Vale, C., Canário, J., Gaspar, M., 2014. Relations between total mercury, methylmercury and selenium in five tissues of Sepia officinalis captured in the south Portuguese coast. Chemosphere 108, 190-196. https://doi.org/10.1016/j. chemosphere.2014.01.037.

Raimundo, J., Ruano, F., Pereira, J., Mil-Homens, M., Brito, P., Vale, C., Caetano, M., 2017. Abnormal mortality of octopus after a storm water event: accumulated lead and lead isotopes as fingerprints. Sci. Total Environ. 581-582, 289-296. https://doi. org/10.1016/j.scitotenv.2016.12.121.

Rangel, M., Pita, C., Oliveira, M.M., Guimarães, M.H., Ballesteros, M., Rainha, R., Sonderblohm, C., Monteiro, P., Oliveira, F., Gonçalves, J.M.S., Pierce, G.J., Erzini, K., 2019. Do fisher associations really represent their members' needs and opinions? The case study of the octopus fishery in the Algarve (south Portugal). Mar. Policy 101, 276-284.

Regueira, M., González, A.F., Guerra, Á., Soares, A., 2013. Reproductive traits of horned octopus Eledone cirrhosa in Atlantic Iberian waters. J. Mar. Biol. Assoc. U.K. 93, 1641-1652. https://doi.org/10.1017/S0025315413000118.

Regueira, M., González, A.F., Guerra, A., 2014. Habitat selection and population spreading of the horned octopus Eledone cirrhosa (Lamarck, 1798) in Galician waters (NW Atlantic). Fish. Res. 152, 66-73. https://doi.org/10.1016/j. fishres.2013.09.003.

Regueira, M., González, Á.F., Guerra, Á., 2015. Determination of age and growth of the horned octopus Eledone cirrhosa (Cephalopoda: octopoda) using stylet increment analysis. Sci. Mar. 79, 71-78. https://doi.org/10.3989/scimar.04137.23a.

Regueira, M., Guerra, Á., Fernández-Jardón, C.M., González, F., 2017. Diet of the horned octopus Eledone cirrhosa in Atlantic Iberian waters: ontogenetic and environmental factors affecting prey ingestion. Hydrobiologia 785, 159-171. https://doi.org/ 10.1007/s10750-016-2916-2.

Regueira, M., Guerra, Á., González, Á.F., 2018. New findings on the behaviour of the horned Octopus Eledone cirrhosa in Captivity. Thalassas 34, 81-86. https://doi.org/ 10.1007/s41208-017-0040-3.

Reis, D.B., Acosta, N.G., Almansa, E., Garrido, D., Andrade, J.P., Sykes, A.V., Rodríguez, C., 2019. Effect of Artemia inherent fatty acid metabolism on the bioavailability of essential fatty acids for Octopus vulgaris paralarvae development. Aquaculture 500, 264-271. https://doi.org/10.1016/j.aquaculture.2018.10.021.

Reusch, T.B.H., Dierking, J., Andersson, H.C., Bonsdorff, E., Carstensen, J., Casini, M., Czajkowski, M., Hasler, B., Hinsby, K., Hyytiäinen, K., Johannesson, K., Jomaa, S., Jormalainen, V., Kuosa, H., Kurland, S., Laikre, L., MacKenzie, B.R., Margonski, P., Melzner, F., Oesterwind, D., Ojaveer, H., Refsgaard, J.C., Sandström, A., Schwarz, G., Tonderski, K., Winder, M., Zandersen, M., 2018. The Baltic Sea as a time machine for the future coastal ocean. Sci. Adv. 4 https://doi.org/10.1126/sciadv.aar8195 eaar8195.

Revill, A., Bloor, I.S.M., Jackson, E.L., 2015. The survival of discarded Sepia officinalis in the English Channel. Fish. Manag. Ecol. 22, 164-171. https://doi.org/10.1111/ fme. 12111.

Ringvold, H., Taite, M., 2018. Using citizen science to obtain data on large, floating gelatinous spheres from NE Atlantic, attributed to egg mass of ommastrephid squid (Oegopsida, Cephalopoda, Mollusca). Mar. Biol. Res. 14, 672-681. https://doi.org/ 10.1080/17451000.2018.1504165.

Rizkalla, S.I., Akel, E.S.H.K., Ragheb, E., 2016. Biodiversity and fisheries of the nontarget catch from bottom trawl, off Alexandria, Mediterranean Sea. Egypt. Reg. Stud. Mar. Sci. 3, 194-204. https://doi.org/10.1016/j.rsma.2015.10.004.

Rjeibi, M., Ezzedine-Najai, S., Chemmam, B., Missaoui, H., 2013. Reproductive biology of Eledone cirrhosa (Cephalopoda: octopodidae) in the northern and eastern tunisian sea (Western and Central Mediterranean). Malacologia 56, 69-84. https://doi.org/ 10.4002/040.056.0205. 
Rjeibi, M., Metian, M., Hajji, T., Guyot, T., Chaouacha-Chékir, R.B., Bustamante, P., 2014. Interspecific and geographical variations of trace metal concentrations in cephalopods from Tunisian waters. Environ. Monit. Assess. 186, 3767-3783. https:// doi.org/10.1007/s10661-014-3656-2.

Rocha, F., Cheikh, I., 2015. Cephalopods in the Canary current large Marine ecosystem. In: Valdés, L., Déniz-González, I. (Eds.), Oceanographic and Biological Features in the Canary Current Large Marine Ecosystem. IOC-UNESCO, Paris. IOC Technical Series, No. 115, pp. 245-255. URI: http://hdl.handle.net/1834/9192.

Rodhouse, P.G.K., Pierce, G.J., Nichols, O.C., Sauer, W.H.H., Arkhipkin, A.I, Laptikhovsky, V.V., Lipinski, M.L., Ramos, J., Gras, M., Kidokoro, H., Sadayasu, K., Pereira, J., Lefkaditou, E., Pita, C., Gasalla, M., Haimovici, M., Sakai, M., Downey, N., 2014. Environmental effects on cephalopod population dynamics: implications for management of fisheries. Advances in Mar. Biol. 67, 99-233.

Rodrigo, A.P., Costa, P.M., 2017. The role of the cephalopod digestive gland in the storage and detoxification of marine pollutants. Front. Physiol. 8, 232. https://doi org /10.3389/fphys. 2017.00232.

Rodrigo, A.P., Costa, P.M., Costa, M.H., Caeiro, S., 2013. Integration of sediment contamination with multi-biomarker responses in a novel potential bioindicator (Sepia officinalis) for risk assessment in impacted estuaries. Ecotoxicology 22, 1538-1554. https://doi.org/10.1007/s10646-013-1140-3.

Rodríguez-González, T., Cerezo Valverde, J., Sykes, A.V., García García, B., 2015. Performance of raw material thermal treatment on formulated feeds for common octopus (Octopus vulgaris) ongrowing. Aquaculture 442, 37-43. https://doi.org/ 10.1016/j.aquaculture.2015.01.035.

Roldán-Wong, N.T., Kidd, K.A., Ceballos-Vázquez, B.P., Arellano-Martínez, M., 2018. Is there a risk to humans from consuming Octopus species from sites with high environmental levels of metals? Bull. Environ. Contam. Toxicol. 101, 796-802 https://doi.org/10.1007/s00128-018-2447-9.

Roo, J., Estefanell, J., Betancor, M.B., Izquierdo, M., Fernández-Palacios, H., Socorro, J., 2017. Effects of supplementation of decapod zoea to Artemia basal diet on fatty acid composition and digestive gland histology in common octopus (Octopus vulgaris) paralarvae. Aquac. Res. 48, 633-645. https://doi.org/10.1111/are.12910.

Rosa, R., O'Dor, R., Pierce, G.J., 2013a. Advances in Squid Biology, Ecology and Fisheries. Part I - Myopsid Squids. Nova Science Publishers, New York.

Rosa, R., Pierce, G., O'dor, R., 2013b. Advances in Squid Biology, Ecology and Fisheries. Part II - Oegopsid Squids. Nova Science Publishers, New York.

Rosa, R., Trubenbach, K., Pimentel, M.S., Boavida-Portugal, J., Faleiro, F., Baptista, M., Dionisio, G., Calado, R., Portner, H.O., Repolho, T., 2014. Differential impacts of ocean acidification and warming on winter and summer progeny of a coastal squid (Loligo vulgaris). J. Exp. Biol. 217, 518-525. https://doi.org/10.1242/jeb.096081.

Rosas-Luis, R., Sánchez, P., 2015. Food and feeding habits of Alloteuthis media in the Western Mediterranean Sea. Mar. Biol. Res. 11, 438-442. https://doi.org/10.1080/ 17451000.2014.962543.

Rosas-Luis, R., Villanueva, R., Sánchez, P., 2014. Trophic habits of the Ommastrephid squid Illex coindetii and Todarodes sagittatus in the northwestern Mediterranean Sea Fish. Res. 152, 21-28. https://doi.org/10.1016/j.fishres.2013.10.009.

Roura, Á, Antón Álvarez-Salgado, X., González, Á.F., Gregori, M., Rosón, G., Otero, J., Guerra, Á., 2016. Life strategies of cephalopod paralarvae in a coastal upwelling system (NW Iberian Peninsula): insights from zooplankton community and spatiotemporal analyses. Fish. Oceanogr. 25, 241-258. https://doi.org/10.1111/ fog. 12151.

Roura, Á., Doyle, S.R., Nande, M., Strugnell, J.M., 2017. You are what you eat: a genomic analysis of the gut microbiome of captive and wild Octopus vulgaris Paralarvae and their zooplankton prey. Front. Physiol. 8, 362. https://doi.org/10.3389/ fphys.2017.00362.

Roura, Á, Amor, M., González, Á.F., Guerra, Á., Barton, E.D., Strugnell, J.M., 2019. Oceanographic processes shape genetic signatures of planktonic cephalopod paralarvae in two upwelling regions. Prog. Oceanogr. 170, 11-27. https://doi.org/ 10.1016/j.pocean.2018.10.005.

Royer, J., Pérès, P., Robin, J.P., 2002. Stock assessment of English Channel loliginid squid: updated depletion method and new analytical method. ICES J. Mar. Sci. 59, 445-457. https://doi.org/10.1006/jmsc.2002.1203.

Safi, G., Martinez, A.S., Le Pabic, C., Le Bihan, E., Robin, J.P., Koueta, N., 2018. Digestive enzyme ratios are good indicators of hatchling yolk reserve and digestive gland maturation in early life stages of cuttlefish Sepia officinalis L.: application of these new tools in ecology and aquaculture. J. Comp. Physiol. B, Biochem. Syst. Environ. Physiol. 188, 57-76. https://doi.org/10.1007/s00360-017-1115-4.

Salman, A., 2015a. Reproductive biology of the elegant cuttlefish (Sepia elegans) in the eastern mediterranean. Turkish J. Fish. Aquat. Sci. 15. https://doi.org/10.4194/ 1303-2712-v15_2_08.

Salman, A., 2015b. Cephalopods of the aegean Sea. In: Katagan, T., Tokac, A., Besiktepe, S., Özturk, B. (Eds.), The Aegean Sea: Marine Biodiversity, Fisheries, Conservation and Governance. Turkish Marine Research Foundation, Istanbul, pp. 226-234.

Salman, A., 2017. Fecundity and spawning strategy of shortfin squid Illex coindetii (Oegopsida: ommastrephidae), in the eastern Mediterranean. Turkish J. Fish. Aquat. Sci. 17, 843-851. https://doi.org/10.4194/1303-2712-v17_4_20.

Samson, J.E., Mooney, T.A., Gussekloo, S.W.S., Hanlon, R.T., 2014. Graded behavioral responses and habituation to sound in the common cuttlefish Sepia officinalis. J. Exp. Biol. 217, 4347-4355. https://doi.org/10.1242/jeb.113365.

Sauer, W.H.H., Gleadall, I.G., Downey-Breedt, N., Doubleday, Z., Gillespie, G., Haimovici, M., Ibáñez, C.M., Katugin, O.N., Leporati, S., Lipinski, M.R., Markaida, U., Ramos, J.E., Rosa, R., Villanueva, R., Arguelles, J., Briceño, F.A., Carrasco, S.A., Che, L.J., Chen, C.-S., Cisneros, R., Conners, E., Crespi-Abril, A.C., Kulik, V.V., Drobyazin, E.N., Emery, T., Fernández-Álvarez, F.A., Furuya, H., González, L.W., Gough, C., Krishnan, P., Kumar, B., Leite, T., Lu, C.-C., Mohamed, K.
S., Nabhitabhata, J., Noro, K., Petchkamnerd, J., Putra, D., Rocliffe, S., Sajikumar, K. K., Sakaguchi, H., Samuel, D., Sasikumar, G., Wada, T., Zheng, X., Tian, Y., Pang, Y., Yamrungrueng, A., Pecl, G., 2019. World Octopus fisheries. Rev. Fish. Sci. Aquac. 1-151. https://doi.org/10.1080/23308249.2019.1680603.

Schwarz, R., Piatkowski, U., Hoving, H., 2018. Impact of environmental temperature on the lifespan of octopods. Mar. Ecol. Prog. Ser. 605, 151-164. https://doi.org/ 10.3354/meps12749.

Şen, H., Akyol, O., 2014. A preliminary study on feeding preference of the musky octopus Eledone moschata (Cephalopoda: octopodidae) in Izmir Bay, Aegean Sea. J. Fish. Sci. 5, 141-145. https://doi.org/10.3153/jfscom.2011017.

Shea, E.K., Judkins, H., Staudinger, M.D., Dimkovikj, V.H., Lindgren, A., Vecchione, M., 2017. Cephalopod biodiversity in the vicinity of Bear Seamount, western North Atlantic based on exploratory trawling from 2000 to 2014. Mar. Biodivers. 47, 699-722. https://doi.org/10.1007/s12526-017-0633-3.

Šifner, S.K., Lijović, S., Isajlović, I., Petrić, M., Vrgoč, N., 2015. Distribution and abundance of bobtail squids (family sepiolidae) in bottom trawling catches of the Northern and Central adriatic Sea. In: Pospišil, M. (Ed.), Proceedings of the 50th Croatian \& 10th International Symposium on Agriculture. University of Zagreb, Opatija, pp. 375-378.

Šifner, S., Damjanović, T., Isajlovic, I., 2018. Distribution, length-weight relationships and reproductive characteristics of Sepia orbignyana Férussac, 1826 in the Northern and Central Adriatic Sea. Cah. Biol. Mar. 59, 43-51. https://doi.org/10.21411/CBM. A.B9291A6E.

Signa, G., Mazzola, A., Di Leonardo, R., Vizzini, S., 2017. Element-specific behaviour and sediment properties modulate transfer and bioaccumulation of trace elements in a highly-contaminated area (Augusta bay, Central Mediterranean Sea). Chemosphere 187, 230-239. https://doi.org/10.1016/j.chemosphere.2017.08.099.

Sigwart, J.D., Lyons, G., Fink, A., Gutowska, M.A., Murray, D., Melzner, F., Houghton, J. D.R., Hu, M.Y.-an, 2016. Elevated pCO2 drives lower growth and yet increased calcification in the early life history of the cuttlefish Sepia officinalis (Mollusca: cephalopoda). ICES J. Mar. Sci. 73, 970-980. https://doi.org/10.1093/icesjms/ fsv188.

Sillero-Ríos, J., Sureda, A., Capó, X., Oliver-Codorniú, M., Arechavala-Lopez, P., 2018. Biomarkers of physiological responses of Octopus vulgaris to different coastal environments in the western Mediterranean Sea. Mar. Pollut. Bull. 128, 240-247. https://doi.org/10.1016/j.marpolbul.2018.01.032.

Silva, P., Cabral, H., Rangel, M., Pereira, J., Pita, C., 2019. Ready for co-management? Portuguese artisanal octopus fishers' preferences for management and knowledge about the resource. Mar. Policy 101, 268-275. https://doi.org/10.1016/j marpol.2018.03.027.

Smith, J.M., Macleod, C.D., Valavanis, V., Hastie, L., Valinassab, T., Bailey, N., Santos, M. B., Pierce, G.J., 2013. Habitat and distribution of post-recruit life stages of the squid Loligo forbesii. Deep. Res. Part II Top. Stud. Oceanogr. 95, 145-159. https://doi.org/ 10.1016/j.dsr2.2013.03.039.

Solé, M., Lenoir, M., Durfort, M., López-Bejar, M., Lombarte, A., André, M., 2013a. Ultrastructural damage of Loligo vulgaris and Illex coindetii statocysts after low frequency sound exposure. PLoS One 8, e78825. https://doi.org/10.1371/journal. pone.0078825.

Solé, M., Lenoir, M., Durfort, M., López-Bejar, M., Lombarte, A., Van Der Schaar, M., André, M., 2013b. Does exposure to noise from human activities compromise sensory information from cephalopod statocysts? Deep. Res. Part II Top. Stud. Oceanogr. 95, 160-181. https://doi.org/10.1016/j.dsr2.2012.10.006.

Solé, M., Sigray, P., Lenoir, M., Van Der Schaar, M., Lalander, E., André, M., 2017. Offshore exposure experiments on cuttlefish indicate received sound pressure and particle motion levels associated with acoustic trauma. Sci. Rep. 7, 45899. https:// doi.org/10.1038/srep45899.

Solow, A.R., 2002. Fisheries recruitment and the North Atlantic Oscillation. Fish. Res. 54, 295-297.

Sonderblohm, C.P., Guimarães, M.H., Pita, C., Rangel, M., Pereira, J., Gonçalves, J.M.S., Erzini, K., 2017. Participatory assessment of management measures for octopus vulgaris pot and trap fishery from southern Portugal. Mar. Policy 75, 133-142. https://doi.org/10.1016/j.marpol.2016.11.004.

Souidenne, D., Florent, I., Dellinger, M., Romdhane, M.S., Grellier, P., Furuya, H., 2016. Redescription of Dicyemennea eledones (Wagener, 1857) (Phylum Dicyemida) from Eledone cirrhosa (Lamarck, 1798) (Mollusca: cephalopoda: octopoda). Syst. Parasitol. 93, 905-915. https://doi.org/10.1007/s11230-016-9659-3.

Steenstrup, J., 1857. VIII.-hectocotylus-formation in Argonauta and Tremoctopus explained by observations on similar formations in the Cephalopoda in general. Ann. Mag. Nat. Hist. 20 (116), 81-114. https://doi.org/10.1080/00222935709487882.

Sykes, A.V., Alves, A., Capaz, J.C., Madeira, C., Couto, A.T., Gonçalves, R.A., Frias, P.A., Leal, I., Andrade, J.P., 2017. Refining tools for studying cuttlefish (Sepia officinalis) reproduction in captivity: in Vivo sexual determination, tagging and DNA collection. Aquaculture 479, 13-16. https://doi.org/10.1016/j.aquaculture.2017.05.021.

Torres, M.A., Vila, Y., Silva, L., Acosta, J.J., Ramos, F., Palomares, M.L.D., Sobrino, I., 2017. Length-weight relationships for 22 crustaceans and cephalopods from the Gulf of Cadiz (SW Spain). Aquat. Living Resour. 30, 12. https://doi.org/10.1051/alr/ 2017010.

Tur, R., Domingues, P., Almansa, E., Lago-Rouco, M.J., García-Fernández, P., Pérez, E., 2019. Spanish Patent No. ES2714930: Procedure for the Culture of Paralarvae of the Common Octopus Octopus vulgaris. Retrieved from: http://invenes.oepm.es/Invene sWeb/detalle? referencia $=$ P201731369.

van der Kooij, J., Engelhard, G.H., Righton, D.A., 2016. Climate change and squid range expansion in the North Sea. J. Biogeogr. 43, 2285-2298. https://doi.org/10.1111/ jbi.12847.

Varela, J.L., Rojo-Nieto, E., Sorell, J.M., Medina, A., 2018. Using stable isotope analysis to assess trophic relationships between Atlantic bluefin tuna (Thunnus thynnus) and 
striped dolphin (Stenella coeruleoalba) in the Strait of Gibraltar. Mar. Environ. Res. 139, 57-63. https://doi.org/10.1016/j.marenvres.2018.04.016.

Vasconcelos, P., Pereira, F., Carvalho, A.N., Gaspar, M.B., 2018. Weight-length relationships and relative growth of the cuttlefish (Sepia officinalis): causes and effects of hypoallometry. Thalassas 34, 323-331. https://doi.org/10.1007/s41208018-0067-0.

Vidal, E.A.G., Von Boletzky, S., 2014. Loligo vulgaris and doryteuthis opalescens. In: Iglesias, J., Fuentes, L., Villanueva, R. (Eds.), Loligo vulgaris and doryteuthis opalescens. Dordrecht, Springer Netherlands, pp. 271-313. https://doi.org/10.1007/ 978-94-017-8648-5_16.

Vieira, H.C., Rendón-von Osten, J., Soares, A.M.V.M., Morgado, F., Abreu, S.N., 2020. Mercury bioaccumulation in the long-fin squid Loligo forbesi near the Mid-Atlantic ridge: implications to human exposure. Ecotoxicol. Environ. Saf. 203, 110957.

Wang, J., Chen, X., Tanaka, K., Cao, J., Chen, Y., 2017. Environmental influences on commercial oceanic ommastrephid squids: a stock assessment perspective. Sci. Mar. 81, 37. https://doi.org/10.3989/scimar.04497.25b.

Wearmouth, V.J., Durkin, O.C., Bloor, I.S.M., McHugh, M.J., Rundle, J., Sims, D.W., 2013. A method for long-term electronic tagging and tracking of juvenile and adult European common cuttlefish Sepia officinalis. J. Exp. Mar. Bio. Ecol. 447, 149-155. https://doi.org/10.1016/j.jembe.2013.02.023.

Xavier, J.C., Allcock, A.L., Cherel, Y., Lipinski, M.R., Pierce, G.J., Rodhouse, P.G.K., Rosa, R., Shea, E.K., Strugnell, J.M., Vidal, E.A.G., Villanueva, R., Ziegler, A., 2015 Future challenges in cephalopod research. J. Mar. Biol. Assoc. U.K. 95, 999-1015. https://doi.org/10.1017/S0025315414000782.
Xavier, J.C., Peck, L.S., Fretwell, P., Turner, J., 2016. Climate change and polar range expansions: could cuttlefish cross the Arctic? Mar. Biol. 163, 78. https://doi.org/ 10.1007/s00227-016-2850-x.

Xavier, J.C., Cherel, Y., Allcock, L., Rosa, R., Sabirov, R.M., Blicher, M.E., Golikov, A.V., 2018. A review on the biodiversity, distribution and trophic role of cephalopods in the Arctic and Antarctic marine ecosystems under a changing ocean. Mar. Biol. 165, 93. https://doi.org/10.1007/s00227-018-3352-9.

Xu, J., Chen, X., Chen, Y., Ding, Q., Tian, S., 2016. The effect of sea surface temperature increase on the potential habitat of Ommastrephes bartramii in the Northwest Pacific Ocean. Acta Oceanolog. Sin. 35, 109-116. https://doi.org/10.1007/s13131-0150782-9.

Yu, W., Chen, X., Chen, Y., Yi, Q., Zhang, Y., 2015. Effects of environmental variations on the abundance of western winter-spring cohort of neon flying squid (Ommastrephes bartramii) in the Northwest Pacific Ocean. Acta Oceanolog. Sin. 34, 43-51. https:// doi.org/10.1007/s13131-015-0707-7.

Yu, W., Chen, X., Yi, Q., Chen, Y., 2016. Influence of oceanic climate variability on stock level of western winter-spring cohort of Ommastrephes bartramii in the Northwest Pacific Ocean. Int. J. Remote Sens. 37, 3974-3994. https://doi.org/10.1080/ 01431161.2016.1204477.

Zarrella, I., Herten, K., Maes, G.E., Tai, S., Yang, M., Seuntjens, E., Ritschard, E.A., Zach, M., Styfhals, R., Sanges, R., Simakov, O., Ponte, G., Fiorito, G., 2019. The survey and reference assisted assembly of the Octopus vulgaris genome. Sci. Data 6, 13. https://doi.org/10.1038/s41597-019-0017-6.

Zavadlav, S., Lacković, I., Kovačević, D.S., Greiner, R., Putnik, P., Filipec, S.V., 2019. Utilizing impedance for quality Assessment of European squid (Loligo vulgaris) during chilled storage. Foods. 8, 624. https://doi.org/10.3390/foods8120624. 